\title{
Morfodinâmica, transporte e proveniência do sistema praia - duna frontal recente entre Itarema e Camocim, litoral oeste do Ceará Morphodynamics, transport and provenance of the recent beach-foredune system between Itarema and Camocim, West Coast of Ceará State (Brazil)
}

\author{
Daniel Rodrigues do Nascimento Junior ${ }^{\text {ad }}$, Lola Natalia Camesi Tossi ${ }^{\text {be }}$, Viktor Ferreira de \\ Oliveira $^{\mathrm{cf}}$, Bruno Brandão de Lucena ${ }^{\mathrm{ag}}$
}

${ }^{a}$ Departamento de Geologia, Universidade Federal do Ceará, ${ }^{b}$ Universidade de Berna, Suíça, ${ }^{c}$ Programa de Pós-Graduação em Geologia, Universidade Federal do Ceará

ddaniel.rodrigues@ufc.br, ${ }^{\mathrm{e}}$ lolacamesi@gmail.com, ${ }^{\mathrm{f}}$ viktorferreira@gmail.com, ${ }^{\mathrm{g}}$ brandao.lucena@gmail.com

\begin{abstract}
Resumo
O litoral oeste cearense entre Itarema e Camocim constitui-se num laboratório natural apropriado ao estudo recente da dinâmica sedimentar. A presença de obstáculos rochosos e hidrodinâmicos e a forte ação do vento efetivo permitem testar padrões de continuidade e inversão da deriva litorânea regional nas areias litorâneas. Este trabalho avaliou morfodinâmica, transporte e proveniência das areias do sistema praia duna frontal através de estudo de campo, granulometria e petrografia de minerais pesados de amostras recentes coletadas na zona de espraiamento e nas cristas de dunas frontais incipientes no trecho mencionado. A diversidade morfológica do sistema aponta para o predomínio de esporões alongados segundo a deriva litorânea regional, a leste, e de praias anexadas sem interrupções com formas eólicas mais extensas, a oeste. Nas areias praiais, a granulometria para todo o intervalo $(100 \mathrm{~km})$ é concordante com deriva litorânea regional para oeste. Em trechos locais, ficou demonstrado que o bloqueio físico exercido pela descarga fluvial de grandes drenagens pode favorecer o transporte no sentido oposto. Nesses trechos, porém, as estatísticas da granulometria são frequentemente pobres, trazendo ressalvas à interpretação e ressaltando a necessidade de maior detalhamento espacial da amostragem. Os minerais pesados tem proveniência primária relacionada a rochas orto- e para-derivadas de alto grau em gnaisses migmatizados do Domínio Médio Coreaú, metatexitos da Unidade Canindé e migmatitos e paragnaisses da Unidade Independência, além de plutônicas do Maciço da Meruoca e corpos menores associados. O índice de proveniência (iRZ) indica diminuição da contribuição relativa das fontes metamórficas no sentido oeste. Já o índice de transporte (iTZ), que diminui no mesmo rumo, teria seu resultado influenciado pelo enriquecimento local renovado em zircão por desembocaduras de diferentes portes e/ou inversões locais na deriva litorânea.
\end{abstract}

Palavras-Chave: morfodinâmica; transporte; proveniência; sistema praia - duna frontal; Ceará

\begin{abstract}
The West Coast of Ceará (Brazil) between Itarema and Camocim is a natural laboratory suitable to the study of recent sedimentary dynamics. The presence of rocky and hydrodynamic obstacles and strong effective winds allow testing either patterns of continuity or reversals of the regional drift current in the coastal sands. This work evaluates morphodynamics, transport and provenance of the sands from the beach-foredune system by means of field study, grain size and heavy minerals petrography analyses of recent samples collected in the swash zone and crests of foredunes along the mentioned stretch. The morphological variety of the system points to the dominance of spits extended following the regional drift current in the east, and attached, uninterrupted beaches with extensive aeolian features at the mainland in the west. In the beaches, the grain size is in agreement to the regional drift current towards west for the entire interval $(100 \mathrm{~km})$. In local intervals, it was demonstrated that the physical blockade made by fluvial discharge of the big drainages could favour a transport in the opposite direction. However, in these stretches, the grain size statistics are frequently poor, bringing restrictions to the interpretation and highlighting the need for a major spatial detailing on sampling. The heavy minerals have primary provenance linked to ortho- and paraderived high-grade rocks from migmatised gneisses of the Médio Coreaú Domain, metatexites of the Canindé Unit, and migmatites and paragneisses of the Independência Unit, as well as plutonic rocks from the Meruoca Massif and other minor related bodies. The provenance index (RZi) indicates a decreasing relative contribution from metamorphic sources towards west. For its turn, the west-decreasing transport index (TZi) would have a result influenced by local enrichments renewing the zircon contribution fed by stream mouths of several sizes and/or reversals in the local alongshore current.
\end{abstract}

Keywords: morphodynamics; transport; provenance; beach-foredune system; Ceará State (Brazil) 


\section{Introdução}

Pesquisas envolvendo proveniência e transporte de sedimentos constituem uma das tarefas mais importantes no entendimento da dinâmica de partículas, desde a origem na área-fonte até a chegada (destino) na bacia sedimentar (Pettijohn 1975, Pettijohn et al. 1987). Da origem ao destino, as partículas sedimentares passam por ciclos de intemperismo, erosão, transporte e deposição que se repetem indefinidamente (reciclagem, retrabalhamento) e repercutem no entendimento do funcionamento interno de sistemas deposicionais (Blatt 1967). A herança de processos sofridos pelas partículas durante esses ciclos pode encontrar-se preservada, tanto em sua constituição mineralógica (proveniência) como em modificações texturais (granulação) e composicionais dinâmicas de sua assembleia original (transporte).

Neste aspecto, sistemas deposicionais costeiros estão entre os que mais tem atraído estudos no Brasil, em parte devido aos interesses econômico e social que despertam, principalmente desde a segunda metade do século passado. Depósitos minerais arenosos densos (minerais pesados) concentrados por dinâmica sedimentar (pláceres) de ilmenita $\left(\mathrm{FeTiO}_{3}\right)$, zircão $\left(\mathrm{ZrSiO}_{4}\right)$ e outros abrangem o primeiro interesse (i.e. Maia et al. 2003). Quanto ao segundo interesse, mencionam-se problemas relacionados a erosão costeira de praias e urbanizações adjacentes (por exemplo, Muehe 1996). Em Fortaleza, por exemplo, a Praia do Futuro tem sido avaliada, entre outros, quanto ao risco de erosão costeira no trabalho de Magini et al. (2007).

No Ceará, a maioria dos estudos envolvendo análise de sedimentos da zona costeira é voltada apenas para sua caracterização granulométrica e, eventualmente, mineralógica (por exemplo, Branco et al. 2005, Vidal et al. 2008, Nascimento et al. 2009). Este é o caso para o trecho do litoral entre os municípios de Itarema e Camocim. Uma análise mais aprofundada permitiria interpretar resultados de granulometria e mineralogia para extrair informações acerca de dinâmica sedimentar recente de proveniência e transporte naquela região.

O trecho da costa cearense entre Itarema e Camocim localiza-se entre as longitudes $39^{\circ} 55^{\prime} \mathrm{W}$ e $40^{\circ} 50^{\prime} \mathrm{W}$, onde abrange cerca de $100 \mathrm{~km}$ de litoral (figura 1). Praias, dunas frontais, campos de dunas livres e lagunas dominam a paisagem, e são em parte subdivididos e/ou conformados por barreiras costeiras e esporões. A orientação geral dos esporões é indicativa da deriva litorânea rumo oeste, característica da maior parte do Estado do Ceará. No entanto, possíveis variações locais na deriva litorânea resultante, em função de proeminências costeiras, como a da Jijoca de Jericoacoara, e/ou desembocaduras fluviais, como a do rio Acaraú, jamais foram estudadas na região. Ademais, por seu porte destacado, este rio constitui um dos melhores candidatos a fornecedor imediato de areias para a zona costeira.
No âmbito particular, este tipo de estudo repercute no melhor entendimento das trocas de massa (areia) e energia (competência de transporte hidrodinâmico e aerodinâmico), tanto internamente ao sistema (entre praia e duna) como externamente a ele (drenagens locais, plataforma continental adjacente etc.). Ressaltase também a importância de compreender a dinâmica recente de transporte nas proximidades de uma área de proteção ambiental (APANA de Jericoacoara), como subsídio na prevenção de problemas de erosão costeira, seja de origem natural ou antropicamente relacionada.

\section{Fisiografia, Geologia e Hidrologia Fluvial}

O litoral oeste cearense se estende de Fortaleza a Bitupitá por cerca de $320 \mathrm{~km}$, onde é caracterizado pela presença de barreiras progradantes, cúspides e esporões praiais, dunas frontais, campos de dunas livres e drenagens de pequeno porte com variável influência de marés. As ondas ocorrem com altura média de $1,1 \mathrm{~m}$ e frequência de 5 s (Maia 1998) com swell de direção NE. As marés são semidiurnas com amplitude média de 3,7 m (DHN 2003). Os tipos morfodinâmicos de praias variam de intermediários a dissipativos (Claudino-Sales \& Peulvast 2004). Em Jijoca de Jericoacoara ocorrem barreiras sobre terrenos mais antigos de barreiras pleistocênicas ou rochas do embasamento, e ainda promontórios e falésias recobertos por dunas. Ali, os campos de dunas ativos compreendem lençóis de areia próximos à costa, com extensas planícies de deflação, grandes barcanas, barcanóides, dunas transversais barcanoidais e dunas parabólicas (Hesp et al. 2009). O prolongamento rumo oeste dos esporões da região indica deriva litorânea no mesmo sentido, característica da maior parte do estado do Ceará. O entanto, a variabilidade média nos seus rumos entre as estações vai de $350^{\circ}$ a $240^{\circ} \mathrm{AZ}$, com maior variabilidade na quadra chuvosa (maio) (CPP 2001). O transporte longitudinal marinho é intenso, atingindo máximos da ordem de $900.000 \mathrm{~m}^{3} / \mathrm{ano}$ (Hesp et al. 2009).

O clima do litoral oeste cearense é tropical quente semi-árido brando, com estação seca no inverno (Aw) da classificação de Köppen-Geiger. O clima é controlado pela Zona de Convergência Intertropical (ZCIT), que consiste na área de confluência de umidade e de ventos alísios de NE e SE e que se desloca sazonalmente em relação ao Equador. A ZCIT se move para sul durante o verão e o outono e para norte durante o inverno, exercendo um controle significante nos regimes pluviométricos e eólicos (Nimer 1979, McGregor \& Nieuwolt 1998). A pluviosidade média histórica é de $925 \mathrm{~mm}$, com chuvas mais frequentes na primeira metade do ano e menores índices pluviométricos de Agosto a Dezembro, mesmo período em que o transporte de sedimentos é maior devido aos ventos (ANA 2016).

Nas duas principais drenagens da região, os rios Acaraú e Coreaú (figura 2), a média histórica anual das vazões é respectivamente de 209 e $316 \mathrm{~m}^{3} / \mathrm{s}$. Sua variação mensal acompanha mais ou menos a estação 
chuvosa, com picos de vazão ligeiramente deslocados entre si e em atraso com respeito às chuvas. As médias anuais da turbidez e da carga sedimentar suspensa dos rios Acaraú e Coreaú são baixas, da ordem de 15 UTN e $22 \mathrm{mg} / \mathrm{L}$ e de $44 \mathrm{UTN}$ e $51 \mathrm{mg} / \mathrm{L}$, respectivamente (ANA 2016).

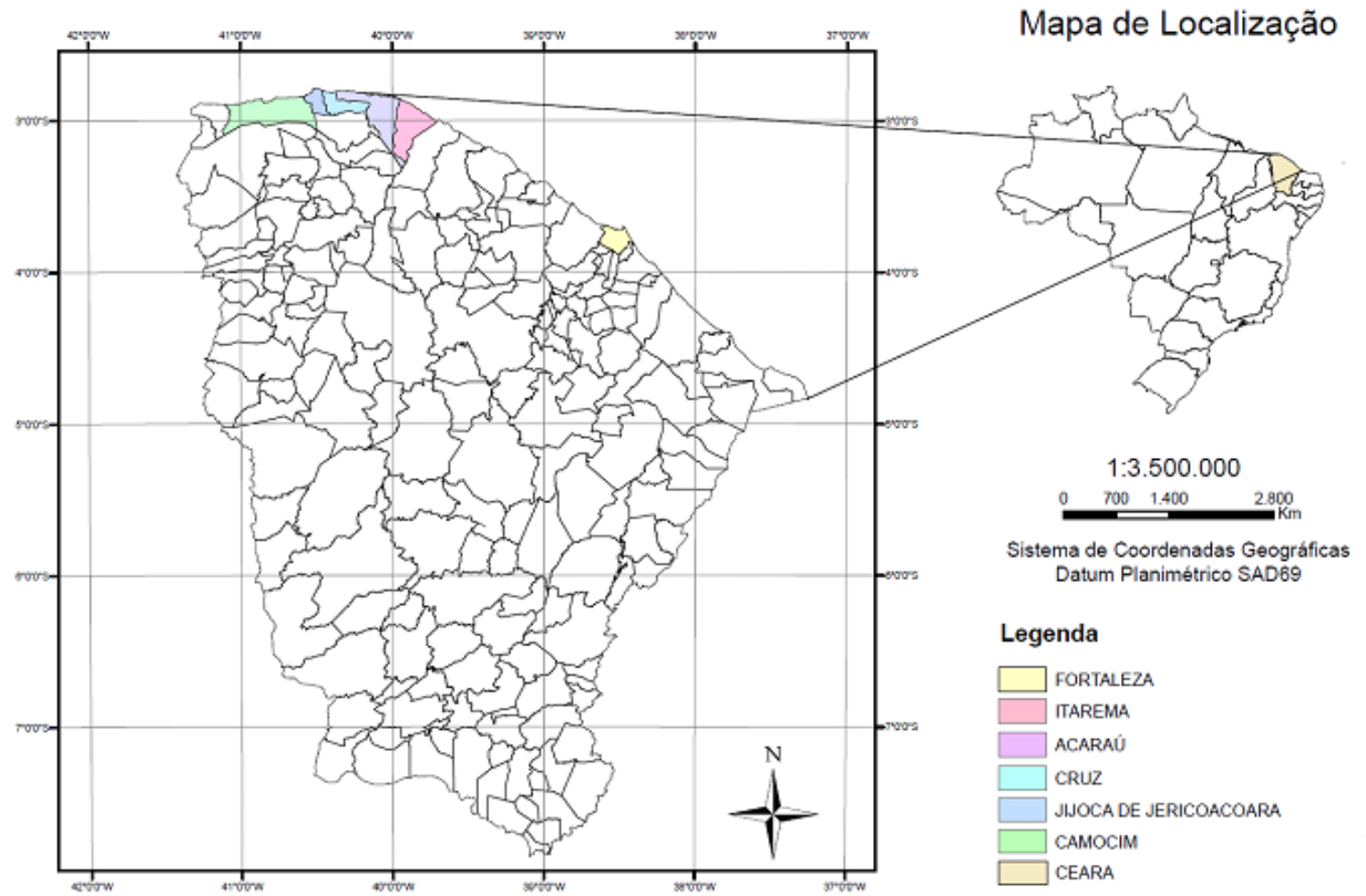

Figura 1. Localização da área de estudo no litoral oeste do Ceará.

No litoral oeste do Ceará, ventos alísios são mais fortes nos meses de estiagem (junho a novembro) quando atingem mais de $7 \mathrm{~m} / \mathrm{s}$, variando sua origem a barlavento de nordeste (janeiro) a sudeste (julho) em função do deslocamento anual do equador térmico da ZCIT (Lima et al. 2000). Sua velocidade média anual é da ordem de $3,8 \mathrm{~m} / \mathrm{s}$ (INMET 2017) e com uma capacidade de transporte estimada em $0,017 \mathrm{~g} / \mathrm{cm}^{2} / \mathrm{s}$ (Morais \& Souza 1971).

\section{Rochas e sedimentos drenados pelas bacias dos rios Acaraú e Coreaú}

No sentido SW-NE, a região drenada pelas bacias hidrográficas dos rios Acaraú e Coreaú compreende cinco províncias geomorfológicas principais: Planalto da Ibiapaba (rochas sedimentares da Bacia do Parnaíba), Depressão Sertaneja (rochas cristalinas dos domínios Ceará Central e Médio Coreaú), Maciços Residuais (rochas cristalinas do Domínio Ceará Central), Glacis Litorâneo (rochas sedimentares da Formação Barreiras) e Planície Costeira (sedimentos inconsolidados) (Lima et al. 2000). Nessas províncias, as bacias hidrográficas dos rios Acaraú e Coreaú cobrem áreas respectivas de $14423 \mathrm{~km}^{2}$ e $10500 \mathrm{~km}^{2}$ (Cavalcante \& Gomes 2011), com sua malha de drenagens distribuída predominantemente sobre terrenos cristalinos nas cabeceiras a sul e sedimentares nas proximidades da foz a norte (figuras 2 e 3 ).
O rio Acaraú nasce no Maciço Residual da Serra das Matas (Sucupira et al. 2006), em um trecho de poucos quilômetros atravessado por granitos peralcalinos neoproterozóicos. Adiante, sua bacia hidrográfica atravessa rochas paraderivadas predominantemente neoproterozóicas da Unidade Canindé (paragnaisses, migmatitos, xistos, mármores, quartzitos e anfibolitos), além de diques de diabásio esparsos (Almeida et al. 2008). Pequenos maciços residuais associados ao Granito Meruoca (granitos alcalinos a peralcalinos, Cambriano - Sial et al. 1981, Gonçalves 2006, Parente et al. 2011) ocorrem adjacentes em um trecho de até 10 km pela depressão atravessada pela bacia de drenagem. Tabuleiros da Formação Barreiras (Mioceno), correspondentes ao Glacis Litorâneo, são atravessados por um intervalo de até $30 \mathrm{~km}$ rumo ao litoral, constituídos de arenitos, conglomerados e lamitos laterizados (ferricretes) em graus variados (Lima et al. 2000). Por fim, o trecho final de poucos quilômetros da bacia hidrográfica rumo à foz abrange areias, lamas e cascalhos recentes do Quaternário, associados às praias, dunas, planícies de maré e aos próprios depósitos aluviais da bacia.

O rio Coreaú nasce no sopé do Planalto da Ibiapaba (COGERH 2010), em um trecho de poucos quilômetros atravessado por arenitos do Grupo Serra Grande (Siluriano - Vaz et al. 2007). Já na Depressão Sertaneja, rochas paraderivadas do Gr. Martinópole (quartzitos, xistos, filitos) e cristalinas (principalmente 
do Neoproterozóico) do Complexo Granja (paragnaisses, ortognaisses, granulitos) e da Unidade Independência (paragnaisses, ortognaisses, metatonalitos, granitos, anfibolitos, calcissilicáticas, quartzitos e diques de diabásio) são as mais aflorantes ao longo de mais de $60 \mathrm{~km}$ (Arthaud 2007). Um pequeno trecho da depressão corre adjacente ao Maciço Residual do Granito Meruoca (granitos alcalinos a peralcalinos, Cambriano). Também apenas uma pequena extensão de poucos quilômetros abrange rochas sedimentares (arcósios e conglomerados polimíticos) da Bacia do Sairi (Cambriano) na extensão final da Depressão Sertaneja (Cavalcante et al. 2003). Ao adentrar o Glacis Litorâneo, as drenagens atravessam tabuleiros miocênicos da Formação Barreiras (arenitos, conglomerados e lamitos laterizados) por até $30 \mathrm{~km}$. Assim como no rio Acaraú, o trecho final da bacia hidrográfica rumo à foz abrange areias, lamas e cascalhos recentes do Quaternário, associados às praias, dunas, planícies de maré e aos próprios depósitos aluviais da bacia.

\section{Materiais e Métodos}

Ao longo da zona costeira entre Itarema e Camocim foram coletadas amostras superficiais (até $10 \mathrm{~cm}$ de profundidade) de cerca de $250 \mathrm{~g}$ de areia da face praial (na zona de espraiamento superior) e da duna frontal incipiente (Hesp 2000) adjacente (na crista), espaçadas entre si por cerca de $2 \mathrm{~km}$ e num trecho total (descontínuo) de aproximadamente $100 \mathrm{~km}$, totalizando 33 pontos de coleta, dos quais apenas dois não apresentaram dunas frontais incipientes. Também foram coletadas amostras-padrões de areias fluviais recentes dos rios Acaraú e Coreaú, em locais à montante e fora da influência de marés enchentes. Todas as amostras foram georreferenciadas, embaladas em saco plástico e codificadas com enumeração de leste para oeste (figura 2). Nos mesmos pontos de amostragem também foram realizadas medidas morfométricas de atitude (direção e mergulho) da face praial, largura entre o espraiamento médio e o sopé da primeira duna frontal (com horário e controle de marés determinados) e altura da duna com auxílio de bússola, trena, GPS e nível topográfico Geodetic NDS 32X com régua (mira) de alumínio. Descrições qualitativas das formas de relevo também foram tomadas em caderneta de campo e pareadas a fotografias dos locais.

Para análise granulométrica as areias foram inicialmente secas em estufa a $60^{\circ}$ por pelo menos duas horas. De cada amostra, 60 a $80 \mathrm{~g}$ foram submetidos a peneiramento em intervalos de $1 \Phi$ da escala de Wentworth (1922) sobre agitador mecânico por 10 minutos. Parâmetros estatísticos dos três primeiros momentos de Pearson (diâmetro médio, desvio padrão, assimetria) foram usados sobre a granulometria para obtenção das características gerais das areias e avaliação de processos modificadores durante seu transporte; no caso específico das areias praiais, o transporte regional e células locais de deriva litorânea foram interpretados. Para tanto, pela regra de McLaren
\& Bowles (1985), o transporte dá-se no sentido do "mais fino/melhor selecionado/mais negativa" (caso B) ou "mais grosso/melhor selecionado/mais positiva" (caso C).

Para separação de minerais pesados a areia retida nas peneiras de 3 e $4 \Phi(0,125$ a $0,062 \mathrm{~mm}$, intervalos de classe areia fina e areia muito fina) foi despejada em funis cheios de bromofórmio $\left(\mathrm{CHBr}_{3}, \mathrm{~d} \approx 2,85 \mathrm{~g} / \mathrm{cm}^{3}\right)$ com válvula de fechamento, no interior de capelas com pressão (ventilação) negativa. Da fração densa, foram separados minerais magnéticos ao ímã de mão comum, protegido por envoltório de plástico. A fração restante (não-magnética) seguiu então para a confecção de lâminas petrográficas permanentes confeccionadas por impregnação de poucos gramas em meio de imersão transparente (bálsamo do Canadá sintético, $\mathrm{n} \approx 1,545$ ). Em seguida, as lâminas foram destinadas à identificação e contagem de minerais pesados transparentes não-micáceos (MPTNM) ao microscópio de luz polarizada. Técnicas comuns de microscopia óptica foram aplicadas na identificação (Kerr 1959, Fujimori \& Ferreira 1979, Trögger 1979), com pequenas adaptações relacionadas à espessura dos grãos (Mange \& Maurer 1992). A contagem foi feita pelo "método das faixas" (ribbon counting: Galehouse 1971), onde foram traçadas linhas-guias com caneta "hidrocor" fina na parte traseira da lâmina, através das quais os minerais são identificados e computados. Foram duas etapas de contagem. Na primeira etapa, toda a assembleia foi identificada e contada. $\mathrm{Na}$ segunda etapa, apenas pares de minerais-índices de proveniência e transporte (Morton \& Hallsworth 1994) foram computados, escolhidos com base em sua disponibilidade verificada na primeira etapa de contagem.

A partir dos resultados de granulometria e minerais pesados foram confeccionados gráficos binários de dispersão de distribuições de frequências em função da distância ao longo das praias. Também foram obtidas retas de regressão, com respectivos coeficientes de correlação linear (r). Para avaliar os resultados de r, o critério foi o nível de significância ou erro I $(\alpha)$, que corresponde à probabilidade de rejeitar uma hipótese nula $\left(\mathrm{H}_{0}\right)$ verdadeira. Como $\mathrm{H}_{0}$, neste caso, afirma a inexistência de correlação significativa $(r \approx 0), \alpha$ pode ser entendido como a probabilidade de aceitar-se correlação inexistente. A estimativa dos valores máximos de $\alpha$ foi feita por interpolação comparando o quociente $t$ do teste de regressão unicaudal de distribuição (t de Student). Foram admitidos resultados de correlação linear com nível menor ou igual a 0,1 (chance de uma em dez de se rejeitar hipótese nula verdadeira).

\section{Resultados e Discussão}

\subsection{Morfologia geral do sistema praia-duna frontal}

No sistema praia-duna frontal de Itarema-Camocim, foram identificados os seguintes elementos morfológicos não-obrigatórios, marinhos e eólicos: berma, cúspides, lago praial, canaleta (runnel), franja 
eólica, nebkha, dunas frontais do tipo terraço, cordão e rampa, e ruptura de deflação (blowout) (tabela 1). O comprimento do conjunto de formas varia de dezenas a pouco mais de uma centena de metros, com tendência de aumento para oeste (figura 4A).

$\mathrm{O}$ elemento obrigatório face praial caracteriza-se por declividades moderadas (média de $4,4^{\circ}$ ), com rumos de mergulho predominantemente voltados para NNE (vetor médio em $19^{\circ} \mathrm{AZ}$ ) (figura 4B). Ocorre ligeira tendência de aumento da declividade para oeste, acompanhado de estreitamento dos perfis praia-duna e diminuição de esporões costeiros.

As formas marinhas de berma (figura 5F) ocorrem frequentemente cobertas por elementos eólicos, principalmente dunas frontais, e tornam-se nestes casos indistintas ao exame visual. A presença de canaletas (runnels) associadas a declividades medianas da face praial atestam para regime morfodinâmico predominantemente intermediário (Dean 1973, Hoefel 1998) (figura 5E). Morfologias associadas às canaletas foram eventualmente observadas durante a maré baixa, e incluem crista de praia (ridge), calha (trough) e barra submersa (bar). Os elementos observados também sugerem predomínio do estado morfodinâmico 5 de Dean (CC/TMB: crista-canal/terraço de maré baixa) (Wright \& Short 1984). Cúspides e lago de praia atestam para variações no estado morfodinâmico e fenômenos de derramamento de água sobre a berma (spillover).

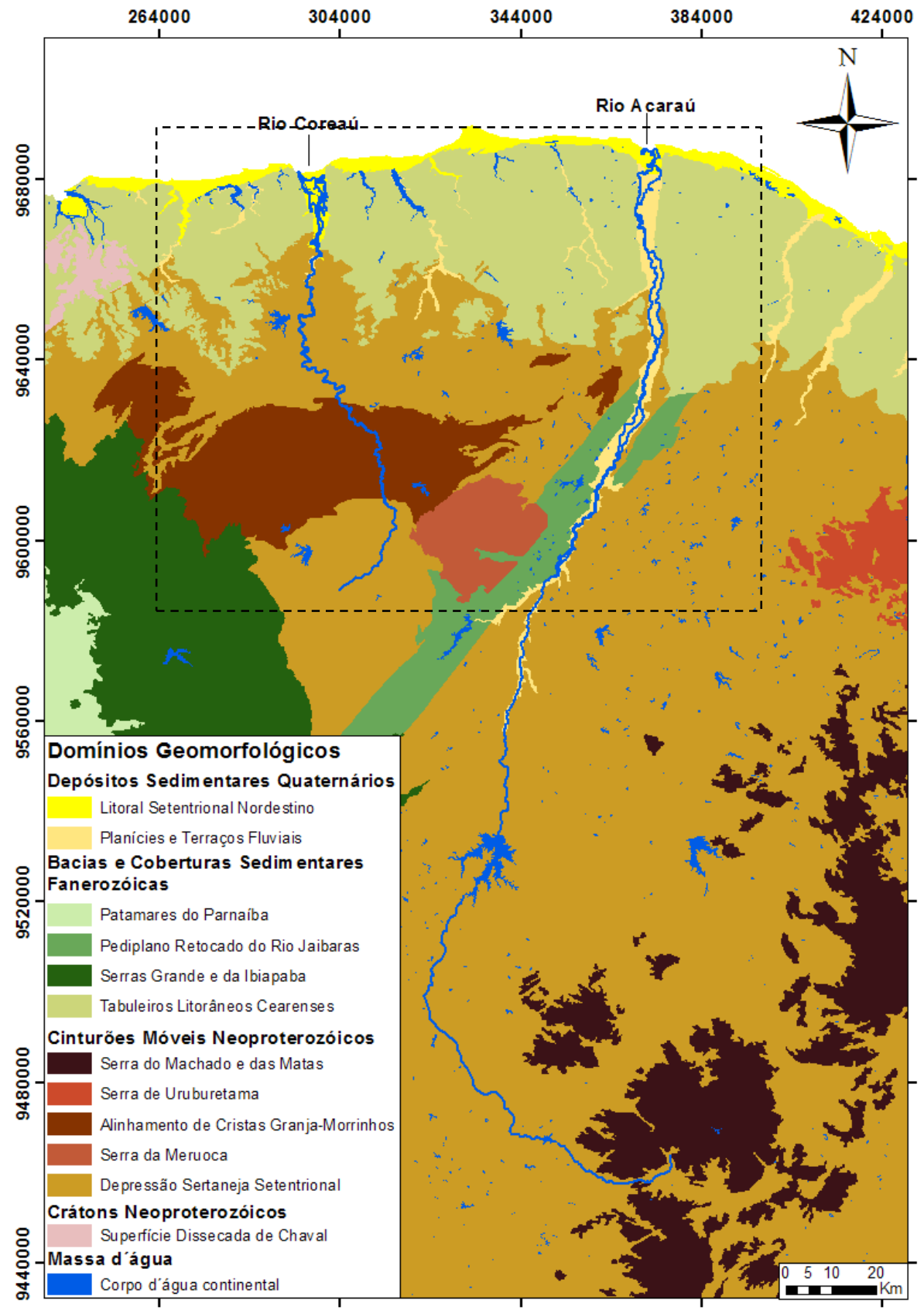

Figura 2: Províncias geomorfológicas das bacias dos rios Acaraú e Coreaú (baseado em Lima et al. 2000). O retângulo pontilhado tem sua geologia destacada na figura 3 abaixo. 


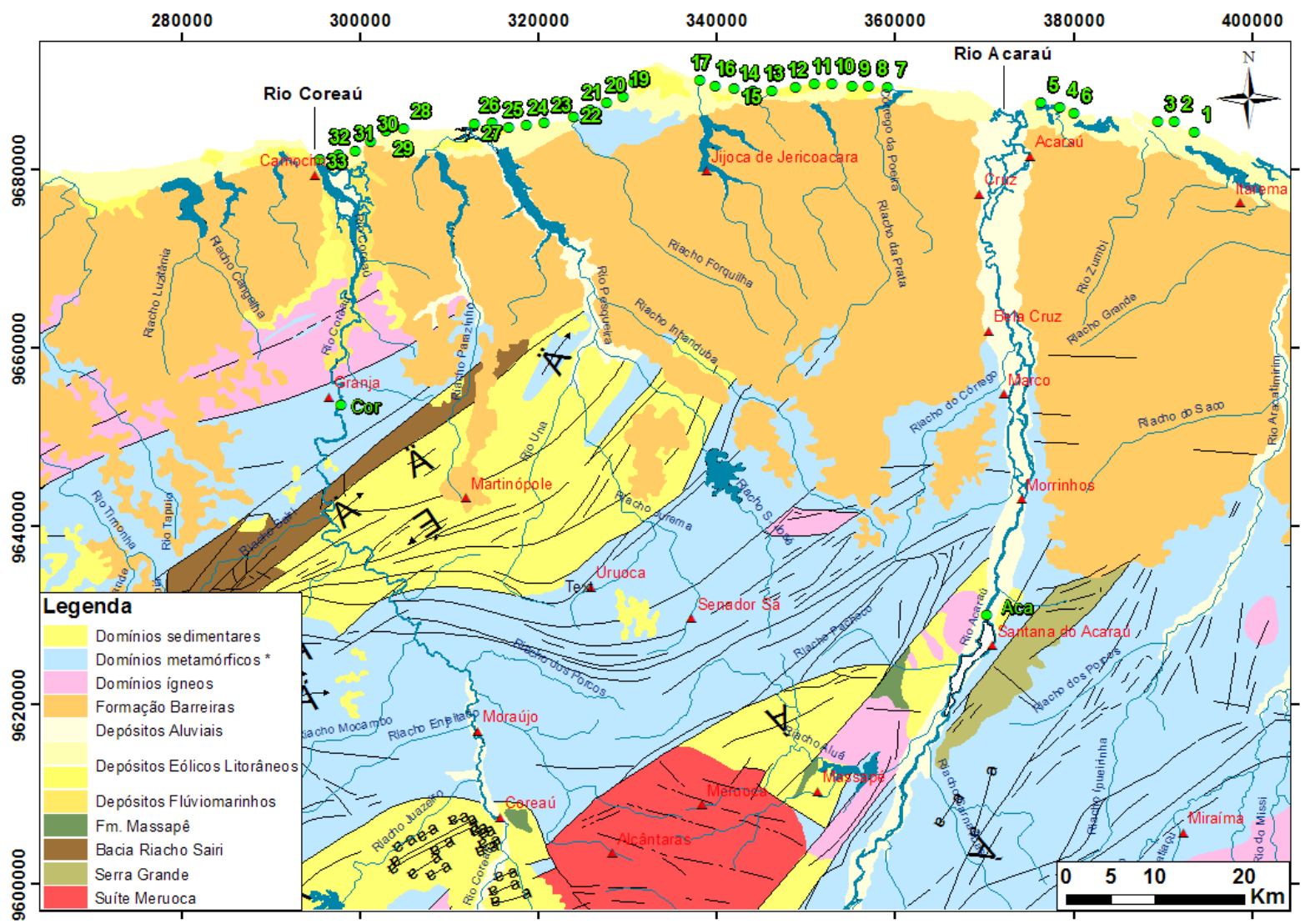

Figura 3: Geologia das bacias hidrográficas dos rios Acaraú e Coreaú (simplificado de Cavalcante et al. 2003), com a localização dos pontos de coleta de amostras deste estudo. Em domínios metamórficos (asterisco), incluem-se as unidades Canindé e Independência, além do Gr. Martinópole e Complexo Granja (indistintos).

As formas eólicas mais comuns incluem tipos menos desenvolvidos (franjas, nebkhas) ou feições mais desenvolvidas (dunas frontais e ruptura de deflação). A única relação clara observada para os elementos morfológicos eólicos foi a das formas menos desenvolvidas com a presença local de drenagens de diferentes tamanhos. Sendo a costa oeste cearense dominada por ventos fortes e baixa pluviosidade (Hesp et al. 2009), esse pode ser um fator crítico para a coesão adicional da areia pela umidade, e que poderia inibir seu volume transportado, como visto em outros trabalhos (Nascimento 2006, Nascimento et al. 2008). No caso dos nebkhas, nota-se frequente amalgamação de suas formas sobre terraços baixos, em associação semelhante ao de dunas frontais do mesmo tipo (figura 5B). Suas dimensões são tipicamente decimétricas na largura e até métrica no comprimento, de elevação decimétrica, alongados segundo o vento prevalecente local, com vegetação na crista e sem face de avalancha (slipface). Quanto às dunas frontais incipientes (DFI), as formas de terraço estendem-se até tipos mais vegetados (dunas frontais estabelecidas), campos de dunas livres (principalmente em Jericoacoara) ou drenagens paralelas à linha de costa (principalmente entre Itarema e Acaraú) (figura 5A). No caso de DFI do tipo cordões, estes são sempre estreitos $(<3 \mathrm{~m})$ e separados por calhas (swales) de mesma dimensão (figuras 4A e 5C). Rampas de DFI ocorrem ancoradas em falésias de outras dunas, onde podem atestar para caráter localmente erosivo (Nascimento 2006) (figura 5D). As elevações das DFI são sempre de poucos metros ( $<5 \mathrm{~m}$ em geral) (figura $4 \mathrm{~A})$. Quanto a rupturas de deflação (blowouts), estas ocorreram em apenas um ponto (ponto 25), desenvolvidas sobre terraços de DFI. Embora em certos casos possam atestar erosão eólica natural em andamento (Sawakuchi et al. 2008), seu caráter pontual sugere influência antrópica na instabilização eólica por atenuação da vegetação (por exemplo, por atividade de veículos sobre as dunas, situação comum naquela região).

\subsection{Características gerais das areias e deriva litorânea regional}

Predominam nas amostras do sistema praia-duna entre Itarema e Camocim areias finas a muito finas (Wentworth 1922), muito bem selecionadas e de assimetria negativa a muito negativa (Folk 1968). Entre as areias de praia e duna frontal incipiente, as diferenças nos três primeiros momentos de Pearson da granulometria em geral são pequenas, da ordem de $0,2 \Phi$, mas chegam a $1 \Phi$ nas áreas em que as areias praiais são alimentadas diretamente por desembocaduras fluviais. Este último fato deve decorrer de uma alimentação renovada em areias imaturas, comparativamente menos retrabalhadas por processos marinhos. 
A

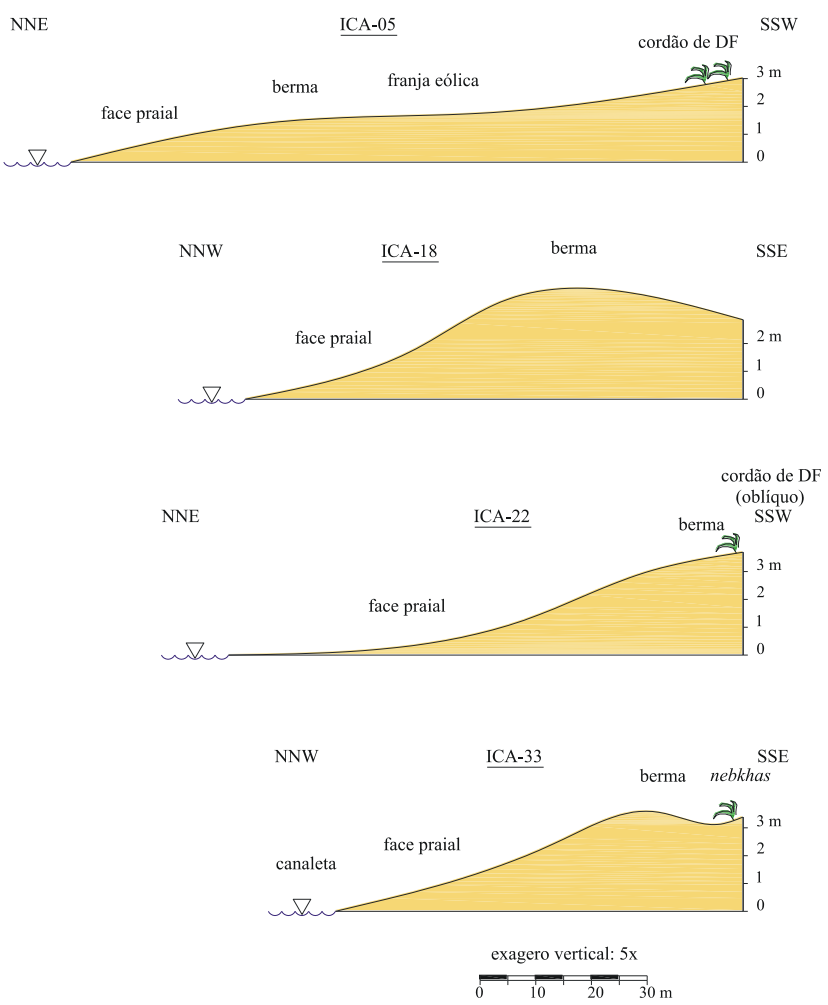

B

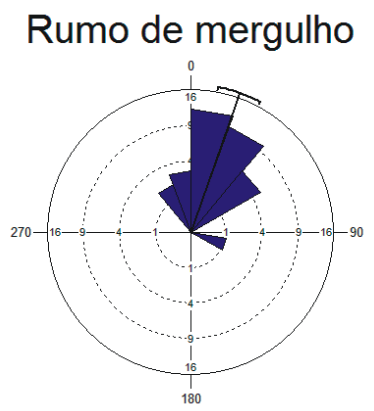

Figura 4: A. Perfis morfométricos comparados de quatro dos pontos mais representativos do sistema praia-duna entre Itarema e Camocim, nivelados em relação à média da maré mínima local. B. Histograma circular de frequências de rumo de mergulho da face de espraiamento. Número de medidas $(\mathrm{n})=33$; vetor médio $(\mu)=19,3^{\circ}$; desvio-padrão circular $(\mu$-circular $)=25,4^{\circ}$.

Tabela 1. Presença e distribuição de elementos morfológicos marinhos e eólicos no sistema praia-duna frontal. DFI: duna frontal incipiente.

\begin{tabular}{|c|c|c|c|c|c|c|c|c|c|c|}
\hline Pontos & Berma* & Cúspides & $\begin{array}{c}\text { Lago } \\
\text { praial }\end{array}$ & Canaleta & $\begin{array}{c}\text { Franja } \\
\text { eólica }\end{array}$ & Nebkha & $\begin{array}{c}\text { DFI - } \\
\text { terraço }\end{array}$ & DFI - cordão & DFI - rampa & Blowout \\
\hline $\begin{array}{c}1 \\
2 \\
3 \\
4 \\
5 \\
6 \\
7 \\
8 \\
9 \\
10 \\
11 \\
12 \\
13 \\
14 \\
15 \\
16 \\
17 \\
18 \\
19 \\
20 \\
21 \\
22 \\
23 \\
24 \\
25 \\
26 \\
27 \\
28 \\
29 \\
30 \\
31 \\
32 \\
33\end{array}$ & X & $\begin{array}{l}X \\
X\end{array}$ & $X$ & $\begin{array}{l}X \\
X \\
X \\
\\
\\
X \\
X \\
X \\
X \\
X\end{array}$ & $\begin{array}{l}\mathrm{X} \\
\mathrm{X} \\
\mathrm{X} \\
\mathrm{X} \\
\mathrm{X}\end{array}$ & $\begin{array}{l}\mathrm{X} \\
\\
\mathrm{X} \\
\mathrm{X} \\
\mathrm{X} \\
\mathrm{X} \\
\mathrm{X} \\
\mathrm{X} \\
\end{array}$ & $\begin{array}{l}X \\
\\
\\
X\end{array}$ & $\begin{array}{l}X \\
X \\
X\end{array}$ & $\begin{array}{l}X \\
X\end{array}$ & $\mathrm{X}$ \\
\hline
\end{tabular}

*Quando exposta. 

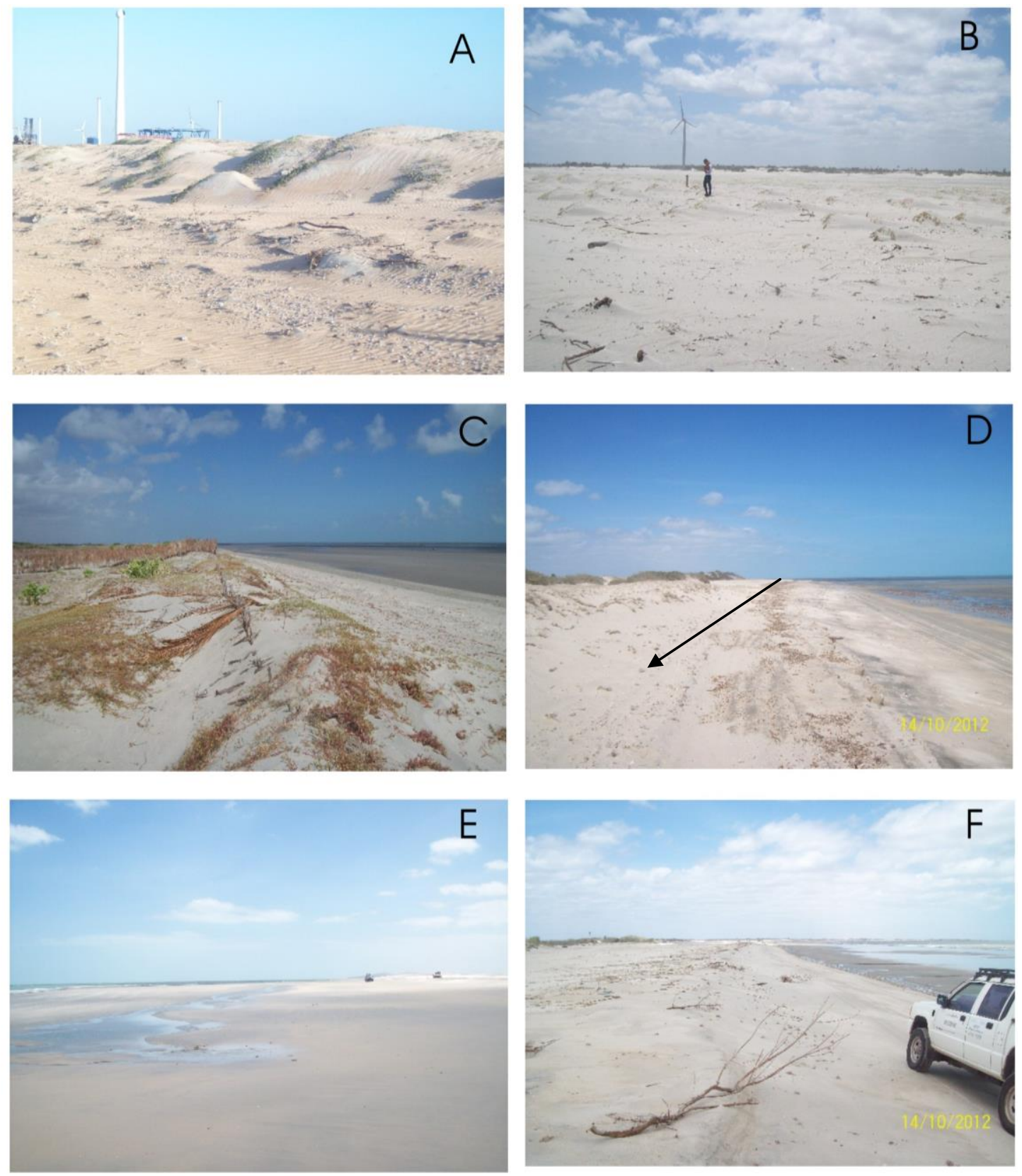

Figura 5: Aspectos morfológicos do sistema praia-duna frontal. A: terraço irregular de DFI, provavelmente em função da construção local de cataventos (ao fundo) (Itarema). B: campo de nebkhas em meio a lençol de areia, rumo de migração WSW (direita) (Praia do Preá, Barrinhas). C: cordão de DFI, terraço de maré baixa ao fundo (Praia de Arpoeiras, Acaraú). D: rampa de DFI sobre falésia irregular de terraço erodido baixo (lado oeste da Ponta de Jericoacoara). E: canaletas expostas durante maré muito baixa, com irregularidades de dunas subaquosas migrantes para oeste (leeside rumo ao observador) (Praia da Tatajuba). F: berma e face praial bem marcados durante maré baixa, terraço de maré baixa ao fundo (Praia de Tatajuba).

Para o universo de todas as amostras, os intervalos de classe areia muito fina, fina e média abrangem mais de $70 \%$ da constituição das areias, com respectivas médias percentuais de $18 \%, 42 \%$ e $19 \%$ para as praias, e $43 \%$, $28 \%$ e $9 \%$ para as dunas frontais incipientes (figura 6). Esse resultado demonstra que, apesar de as praias abrangerem a fonte sedimentar imediata das dunas em questão, o transporte aerodinâmico parece ter modificado a granulometria de modo significativo nas dunas, com destaque para os padrões de assimetria, que se comportam de modo oposto ao longo do sistema.

$\mathrm{O}$ diâmetro médio apresentou baixo desvio-padrão de seus dados, tanto entre amostras de praias $(0,44 \Phi)$ como entre as de dunas $(0,29 \Phi)$. O fato denota grande homogeneidade das amostras entre si, a despeito de enriquecerem-se em areia fina para W. Nas praias, valores médios de diâmetro médio vão de 2,30Ф a $3,18 \Phi$. Nas dunas, variam no mesmo intervalo de $2,99 \Phi$ para $2,27 \Phi$.

As amostras de praias apresentaram grau de seleção moderado (Folk 1968), com 60,6\% dos sedimentos moderadamente bem selecionados e o restante com pior grau de seleção. Este resultado é provavelmente influenciado por aporte fluvial de areias pouco retrabalhadas. As amostras das dunas frontais incipientes apresentam grau de seleção mais alto, com 
$48,4 \%$ das amostras muito bem selecionadas e $25,8 \%$ de amostras com grau de seleção ainda mais alto (bem selecionadas e muito bem selecionadas). Há tendência de melhora da seleção granulométrica das amostras rumo $\mathrm{W}$ ao longo das praias, com oscilação de valores em torno de $1 \Phi$ nos primeiros pontos e em torno de $0,60 \Phi$ nos pontos finais. Ocorre uma situação inversa com as dunas frontais, onde a seleção piora no rumo $\mathrm{W}$, indicando falta de homogeneidade ou interferência no transporte eólico; os valores vão de 0,49 a $0,88 \Phi$ (figura 6).

Nas praias a assimetria mostrou-se muito negativa em 79\% das amostras (Folk 1968), o que possui alto contraste com a distribuição das demais, compostas de areias assimetricamente muito positivas. Nas dunas, permanece o predomínio de assimetria muito negativa com $48,4 \%$, mas a maior parte do restante $(35,5 \%)$ é composta de areias assimetricamente muito positivas e positivas. A ocorrência de amostras simétricas e negativas nas areias de dunas frontais demonstra redução do contraste entre as amostras em termos de assimetria quando comparadas às amostras de praias entre si. Neste parâmetro, observam-se tendências de variação longitudinal opostas entre praia e duna frontal. Ao longo do trecho analisado, a distribuição granulométrica das praias torna-se assimetricamente mais negativa para $\mathrm{W}$, enquanto as dunas tornam-se mais positivas no mesmo rumo (figura 6). Aparentemente, o transporte pelo vento, como agente selecionador, é muito competente em deslocar a cauda da curva granulométrica para as frações mais finas, como visto em outros estudos (por exemplo, Nascimento et al. 2005). Essa tendência tem sido encontrada mesmo para dunas costeiras onde o transporte a partir da área fonte praial é curto, como é o caso de dunas frontais incipientes (Giannini et al. 2003).
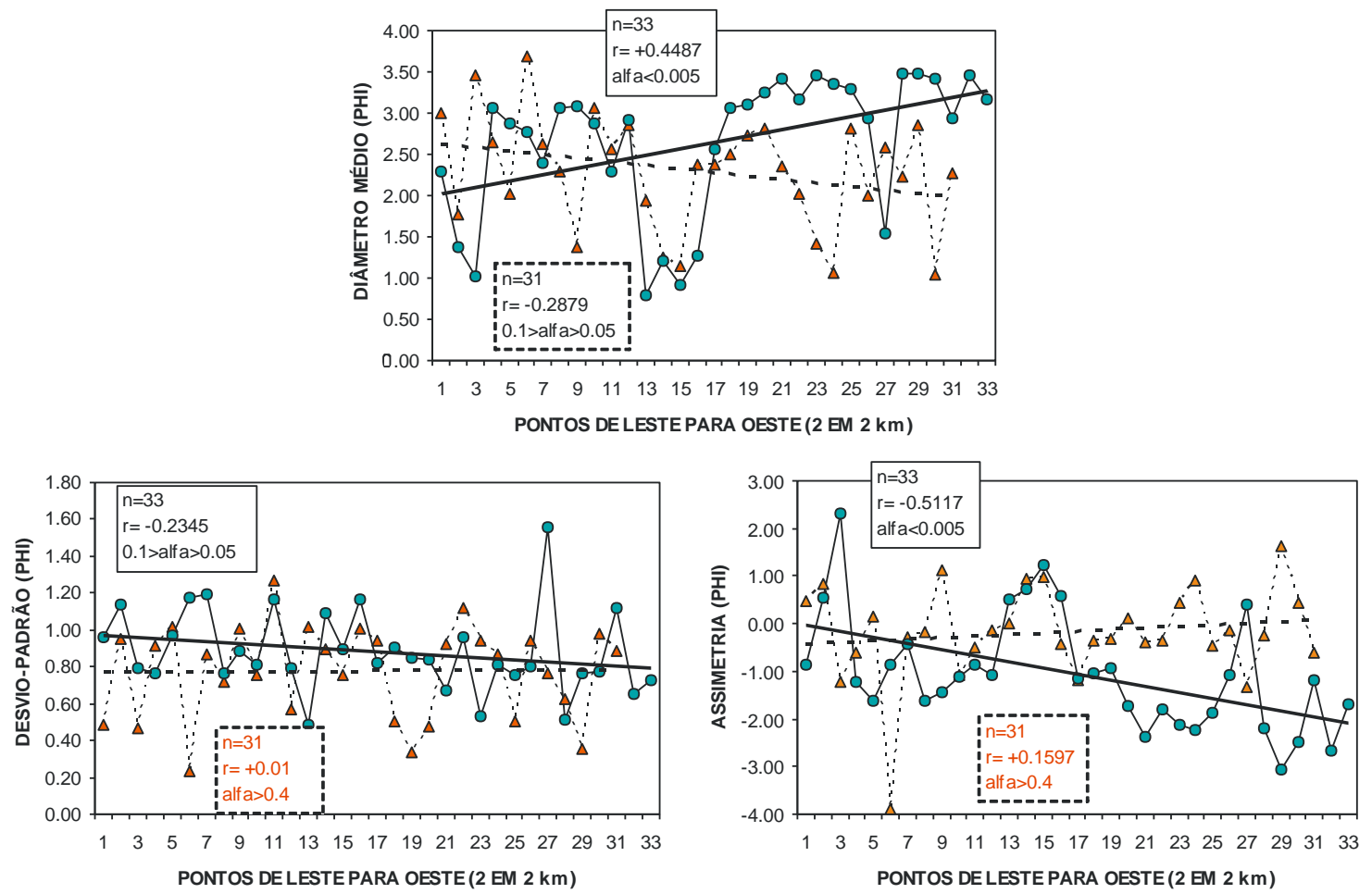

Figura 6: Comparação entre tendências de distribuição dos três primeiros momentos de Pearson sobre a granulometria de areias praiais (círculos azuis) e de dunas frontais incipientes (triângulos alaranjados) entre Itarema e Camocim. Entre os pontos, nas linhas de tendências e nos retângulos de resultados estatísticos as linhas contínuas denotam amostras de praias e, as tracejadas, amostras de dunas. Os símbolos $\mathrm{n}$, $\mathrm{r}$ e $\alpha$ (alfa) correspondem respectivamente ao número de amostras, coeficiente de correlação linear e nível de significância (por teste de regressão unicaudal t de Student).

Verifica-se nas areias das praias, rumo $\mathrm{W}$, tendência geral de afinamento, melhora do grau de seleção (diminuição do desvio-padrão) e assimetria mais negativa (figura 6). Em todos os parâmetros, o teste estatístico por regressão linear obteve resultados muito consistentes (níveis de significância para $\mathrm{H}_{0}$ sempre inferiores a 0,1). Esta combinação entre os três primeiros momentos de Pearson da distribuição granulométrica é concordante com um dos padrões indicadores de transporte (caso B) de McLaren \& Bowles (1985). Entre Itarema e Camocim, este resultado pode ser atribuído ao predomínio, em escala maior, da reconhecida corrente de deriva litorânea neste sentido, como evidente, por exemplo, na orientação de proeminências costeiras (esporões, barreiras etc.) voltadas para o mesmo rumo (Hesp et al. 2009).

Quando comparados, os parâmetros da distribuição granulométrica apresentam boa correlação linear em geral, sendo do tipo positiva entre desvio-padrão e assimetria e negativa nos demais casos. Nas praias, entre assimetria e desvio-padrão, o nível de correlação destoa dos demais e se apresenta excelente $(r=-0,94$; $\alpha<0,005$ ) (figura 7). 

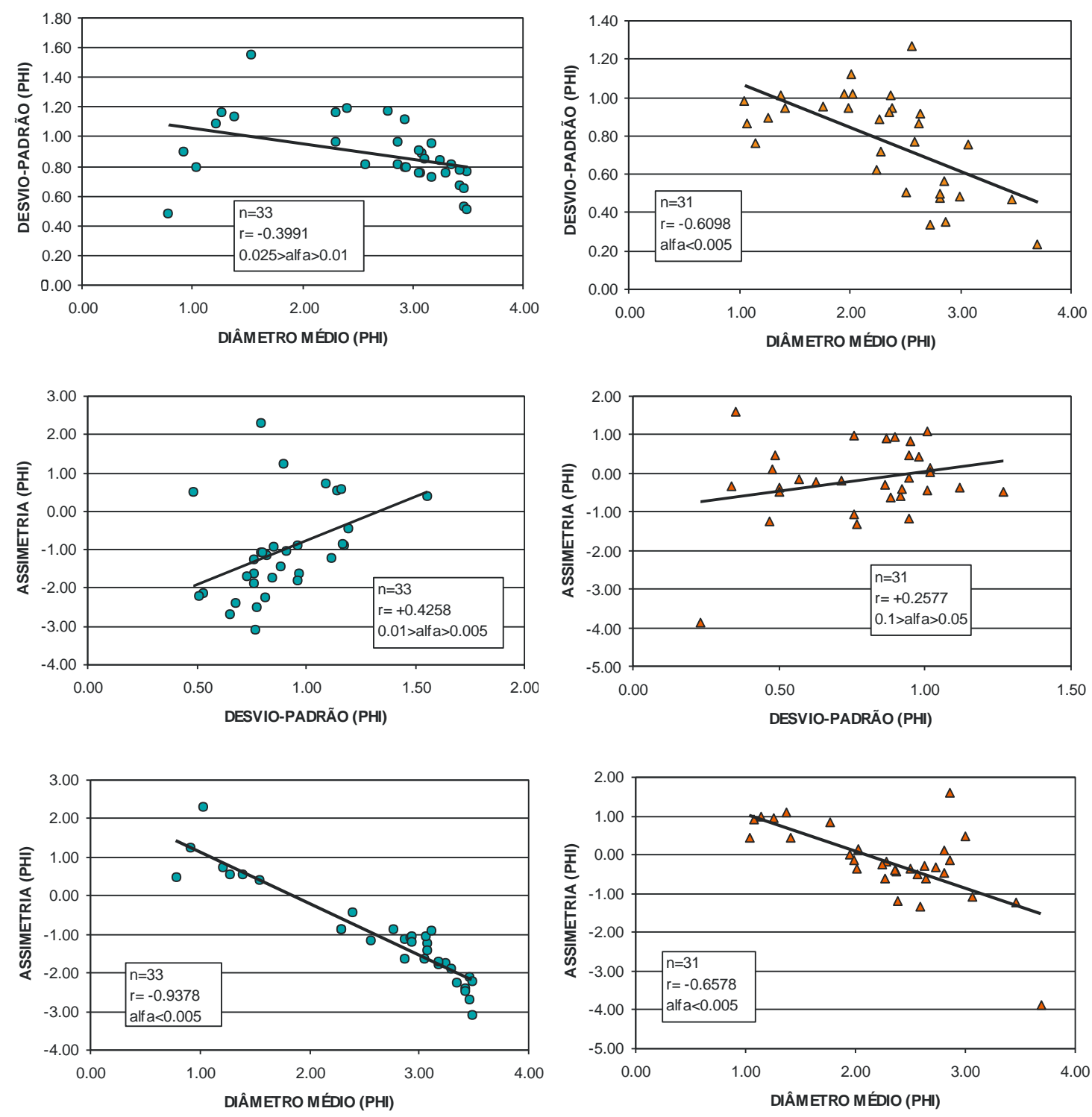

Figura 7: Correlação entre parâmetros dos três primeiros momentos de Pearson em amostras de praias (círculos azuis) e dunas (triângulos alaranjados). Os símbolos n, r e $\alpha$ (alfa) correspondem respectivamente a número de amostras, coeficiente de correlação linear e nível de significância (por teste de regressão unicaudal t de Student).

\subsection{Padrões de deriva litorânea local e inversões}

\subsubsection{Pontos 1 a 3: esporão do rio Itarema}

O esporão do rio Itarema corresponde a uma projeção de areia emersa, estreita (até $300 \mathrm{~m}$ de largura), alongada E-W por $5 \mathrm{~km}$ segundo a deriva regional, separado em maior parte do continente pelo rio Itarema, que corre paralelo a ele, e entre tanques de carcinicultura (figura 8). Esta proeminência é uma das integrantes que passam a ocorrer na zona costeira desde Almofala (a leste). A intensa dinâmica sedimentar dessas feições pode ser testemunhada por sua constante mudança de forma, alongamento e rompimento de canais/atalhos, como visto em imagens de satélite e fotografias aéreas de diferentes épocas. A deriva litorânea deste intervalo acompanha o transporte regional para oeste, mas com padrão de transporte do caso C (McLaren \& Bowles 1985). Isso indica que as areias amostradas correspondem a sedimento residualmente concentrado (lag), material incapaz ou de difícil transporte ante a corrente de deriva litorânea. $\mathrm{O}$ caso $\mathrm{C}$ de transporte é incomum em sistemas praiais, mas no esporão de Itarema poderia ser resultado de bimodalidade granulométrica em função da presença de areias texturalmente imaturas fornecidas pelo rio Itarema que, por seu pequeno porte, opera no local como canal de maré (tidal creek). Outro fator ressaltado é o da presença local de geradores de energia eólica (cata-ventos) e viveiros de camarão recentemente estabelecidos, com material agregado de construção trazido para as adjacências do esporão que poderia ser retrabalhado pela deriva local. Seja qual for o caso, esta interpretação possui ressalvas em função do pobre nível de significância do desvio-padrão $(0,4>\alpha>0,3)$, parâmetro que é o principal indicador de transporte (figura 9). 


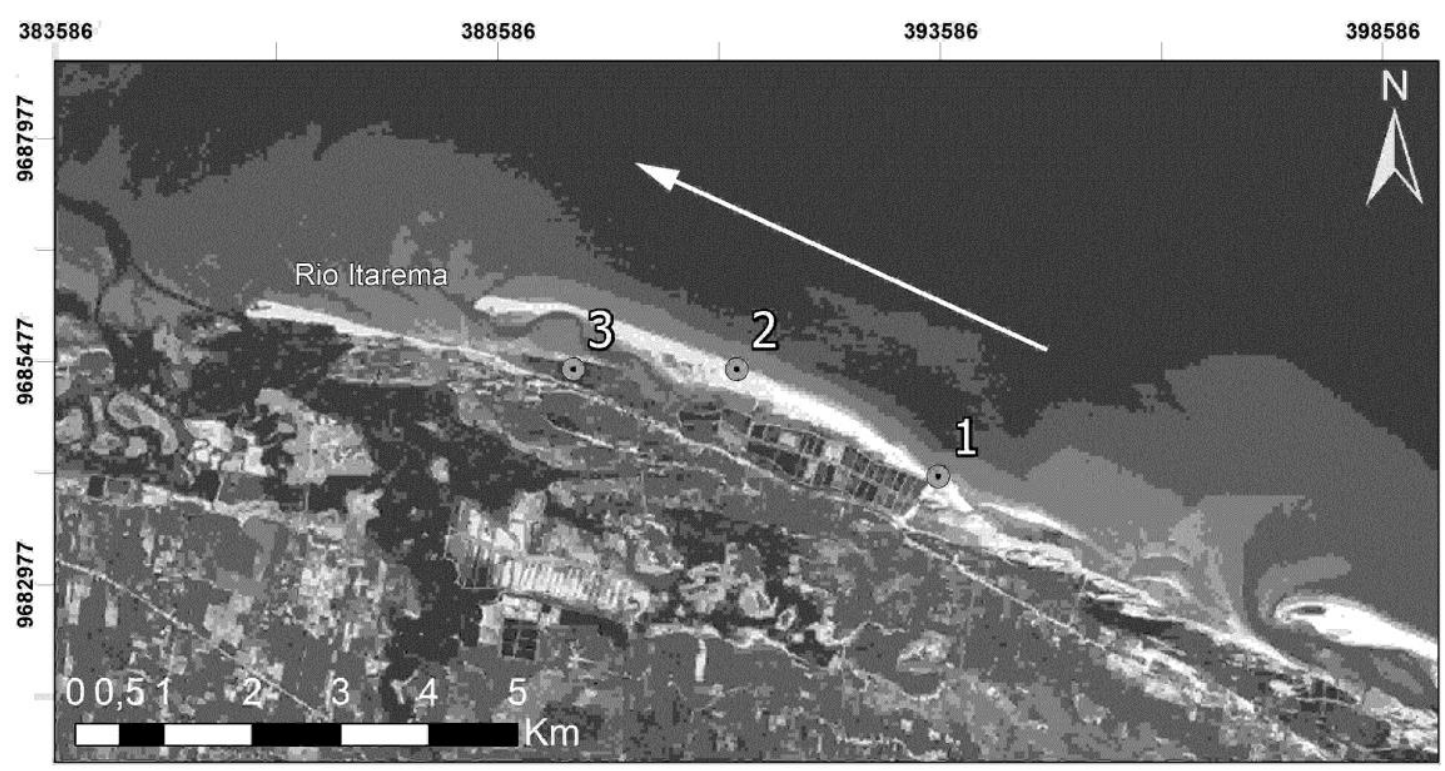

Figura 8: Esporão do rio Itarema, com padrão de transporte do caso C seguindo a deriva regional para oeste. Data da imagem: 16/11/2012.
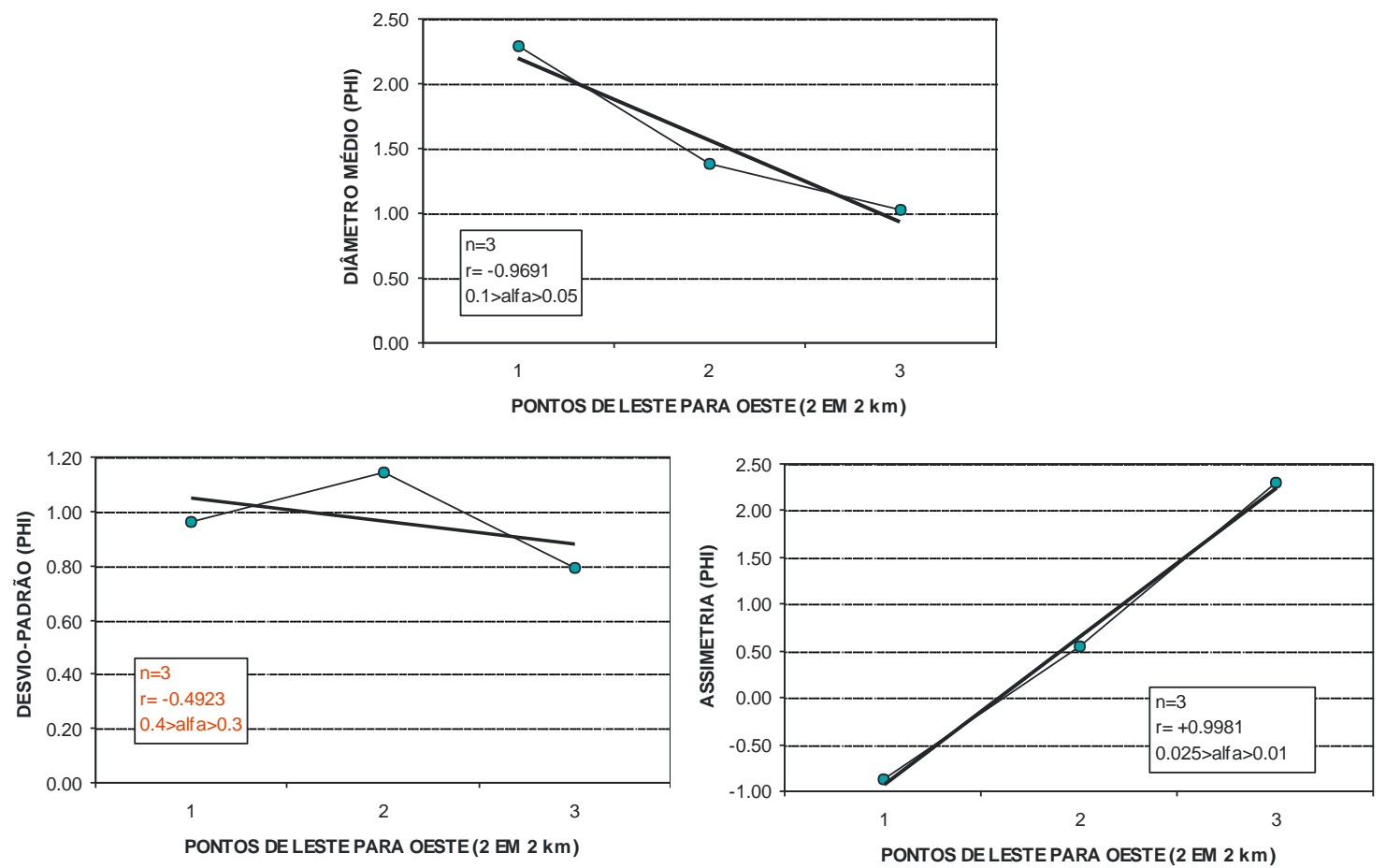

Figura 9: Comparação entre tendências de distribuição dos parâmetros estatísticos granulométricos de areias praiais entre os pontos 1 e 3 (rumo E-W). Os símbolos $\mathrm{n}, \mathrm{r}$ e $\alpha$ correspondem respectivamente ao número de amostras, coeficiente de correlação linear e nível de significância (por teste de regressão unicaudal t de Student).

\subsubsection{Pontos 4 a 6: barreira da praia de Arpoeiras (Acaraú)}

Os esporões de areia diminuem e dão lugar a barreiras estreitas (de 100 a $200 \mathrm{~m}$ de largura) de comprimento quilométrico, anexadas ao continente a partir da ilha dos Coqueiros (Acaraú). A barreira da praia de Arpoeiras é uma das mais extensas (5 km), e encontra-se limitada por canais de maré extensos (quilômetros) e muito ramificados, correspondentes aos rios Imburana (leste) e Arpoeiras (oeste). Este último poderia corresponder a um atalho histórico, surgido nos últimos anos ou décadas, que passou a separar uma porção da barreira junto ao rio Acaraú (a oeste), o maior e mais importante da região (figura 10).

Observa-se inversão no rumo de deriva litorânea local com relação ao padrão regional, novamente por transporte do caso C (figura 11). No entanto, o resultado da assimetria é estatisticamente pobre e há extensões locais de esporões que parecem contradizer o resultado geral, ou que ele seria válido apenas entre os pontos 4 e 5 . Uma possibilidade para isto seria um 
efeito de circulação local na desembocadura de marés a leste da Ilha dos Coqueiros e que requereria maior detalhamento na área (mais amostras em intervalos menores).

Alternativamente, caso exista para todo o intervalo, esta inversão local pode ser função de um bloqueio hidráulico ou "efeito de molhe" (groyne effect) forçado pela descarga do rio Acaraú. A linha de costa mais avançada $(1 \mathrm{~km})$ rumo ao mar na margem oeste do rio ainda seria mantenedora deste bloqueio mesmo em

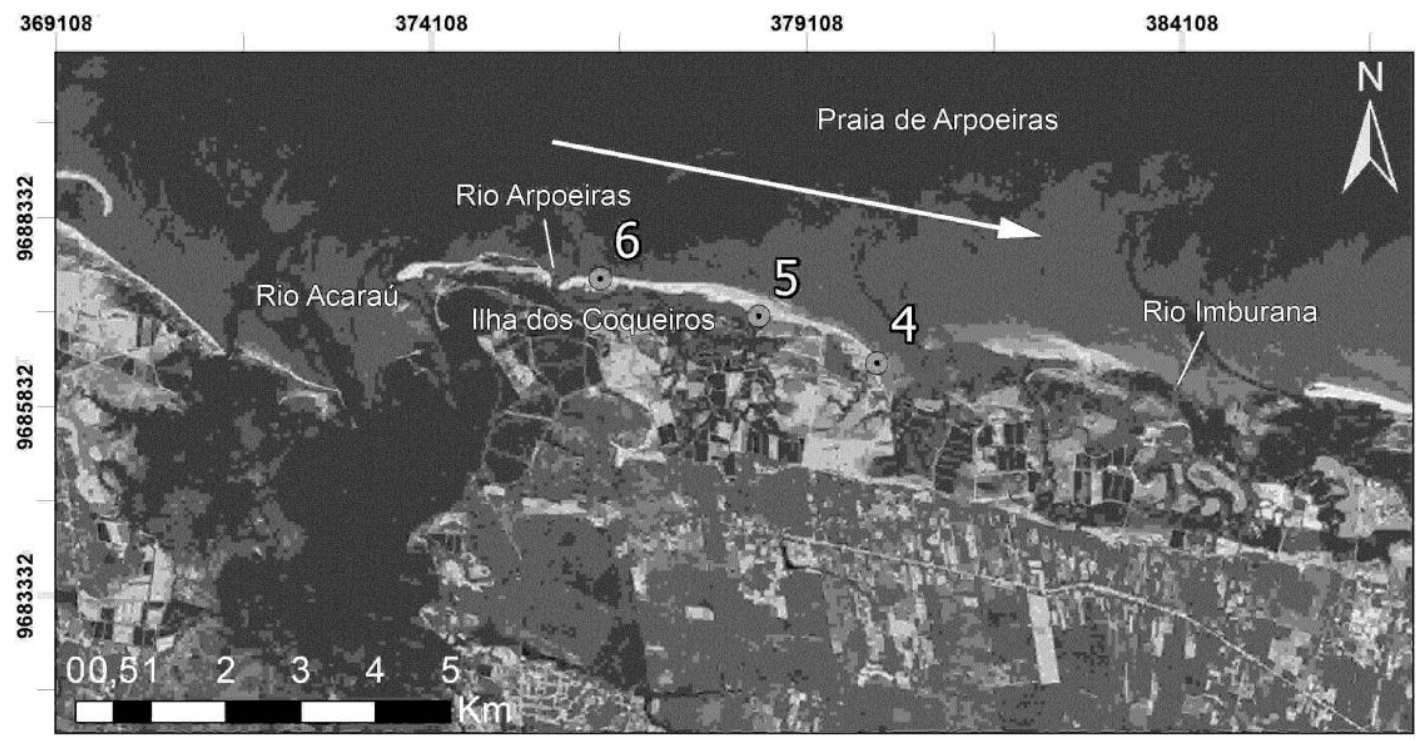

Figura 10: Barreira da praia de Arpoeiras, com padrão de transporte do caso C, contrário à deriva regional. Data da imagem: 16/11/2012.
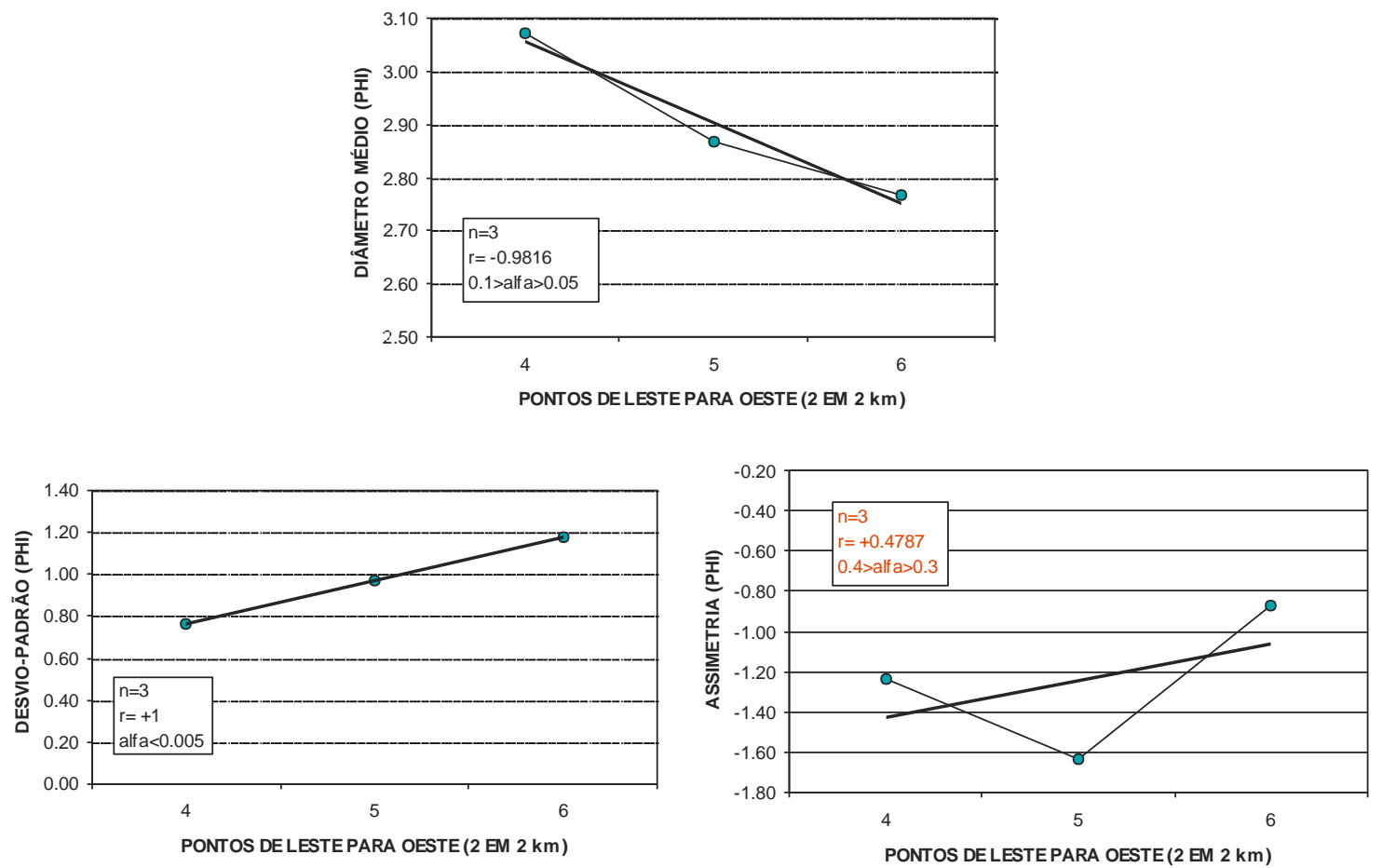

Figura 11: Comparação entre tendências de distribuição dos parâmetros estatísticos granulométricos de areias praiais entre os pontos 4 e 6 (rumo EW). Os símbolos n, $\mathrm{r}$ e $\alpha$ correspondem respectivamente ao número de amostras, coeficiente de correlação linear e nível de significância (por teste de regressão unicaudal $t$ de Student). 


\subsubsection{Pontos 7 a 14: praia do Preá, localidade de Barrinhas}

A praia do Preá estende-se a partir da margem oeste do rio Acaraú até a ponta de Jericoacoara, sendo os primeiros $25 \mathrm{~km}$ pertencentes à localidade de Barrinhas. Neste trecho, as barreiras e esporões costeiros dão lugar a extensões de areia anexadas ao continente, mas a presença de pequenos canais de maré (largura decamétrica a métrica) paralelos à linha de costa ainda é evidente (figura 12). A corrente de deriva local segue o padrão da regional pelo caso C. O resultado, porém, possui ressalvas pela pobreza estatística do resultado de desvio padrão, justamente o melhor indicador de transporte. Este ponto em particular corresponde a um local onde ocorre suave mudança na orientação da linha de costa, de WSEWNW para ENE-ESE. O mesmo ponto coincide com a extensão rumo ao mar da "lagoa" (lago) do Paraíso, um antigo vale aluvial afogado, provável depressão herdada e escavada em depósitos miocênicos da Formação Barreiras. Isso indicaria que esta unidade estratigráfica aproxima-se da costa naquele ponto, e seria a provável razão da mudança em seu contorno. Formada por material mais competente, inclusive com porções lateríticas, a Fm. Barreiras teria influência na mudança de padrão granulométrico a partir do ponto 11 pelo bloqueio mencionado. Porém, a divisão do intervalo ao trecho 11 só se torna estatisticamente aceitável pela exclusão do ponto 7 , e a deriva ainda seria contraditória com a extensão local de esporões. Uma vez mais, o resultado sugere que a diminuição do espaço de amostragem pela coleta de mais areias seria o ideal neste trecho (figura 13).

\subsubsection{Pontos 15 a 21: adjacências da ponta de Jericoacoara}

A ponta de Jericoacoara é uma projeção rumo ao mar da linha de costa de $5 \mathrm{~km}$, ancorada em quartzitos neoproterozóicos da Formação São Joaquim (Cavalcante et al. 2003). A presença das rochas cristalinas também teria permitido uma maior extensão da Fm. Barreiras naquele local (figura 14).

Apesar de ser a mais expressiva proeminência costeira da região, as adjacências da ponta de Jericoacoara apresentam deriva litorânea local pelo caso B (areias ativamente transportadas pelas correntes) em conformidade com aquela vista regionalmente (figura 15). Esse resultado é plausível para o lado leste, que recebe o fluxo regional frontalmente, apesar do desvio padrão estatisticamente fraco. Para o lado oeste, entretanto, um bloqueio físico seria o esperado, capaz de inverter a deriva local, como já visto nas proximidades da desembocadura do rio Acaraú. Uma possibilidade é a de que rumos de deriva para SW, ocorrentes na região (CPP 2001), sofram menos bloqueio pelo promontório de Jericoacoara.

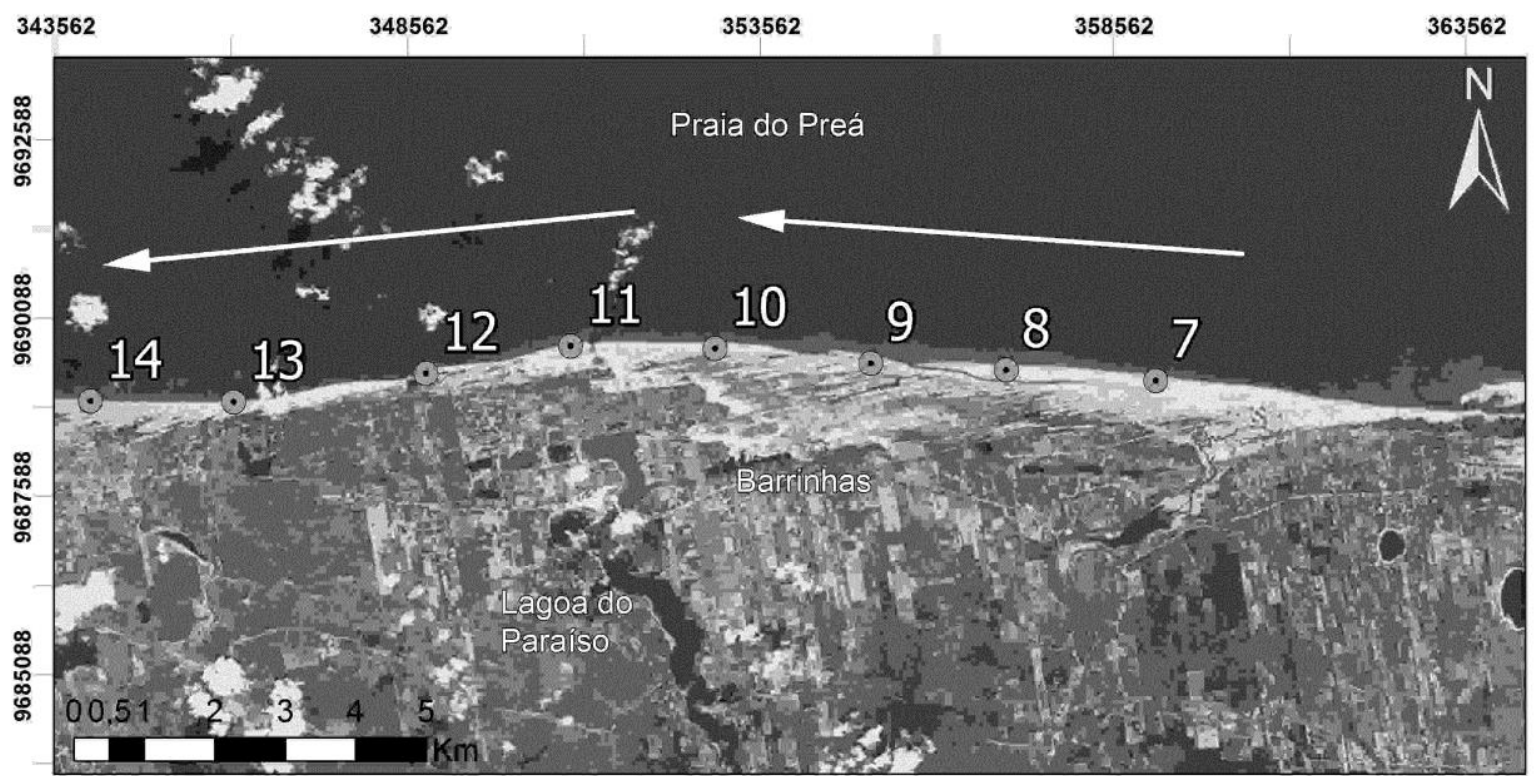

Figura 12: Extensão da praia do Preá na localidade de Barrinhas, com padrões do caso B, contrários à deriva regional para oeste. Data da imagem: $16 / 11 / 2012$. 

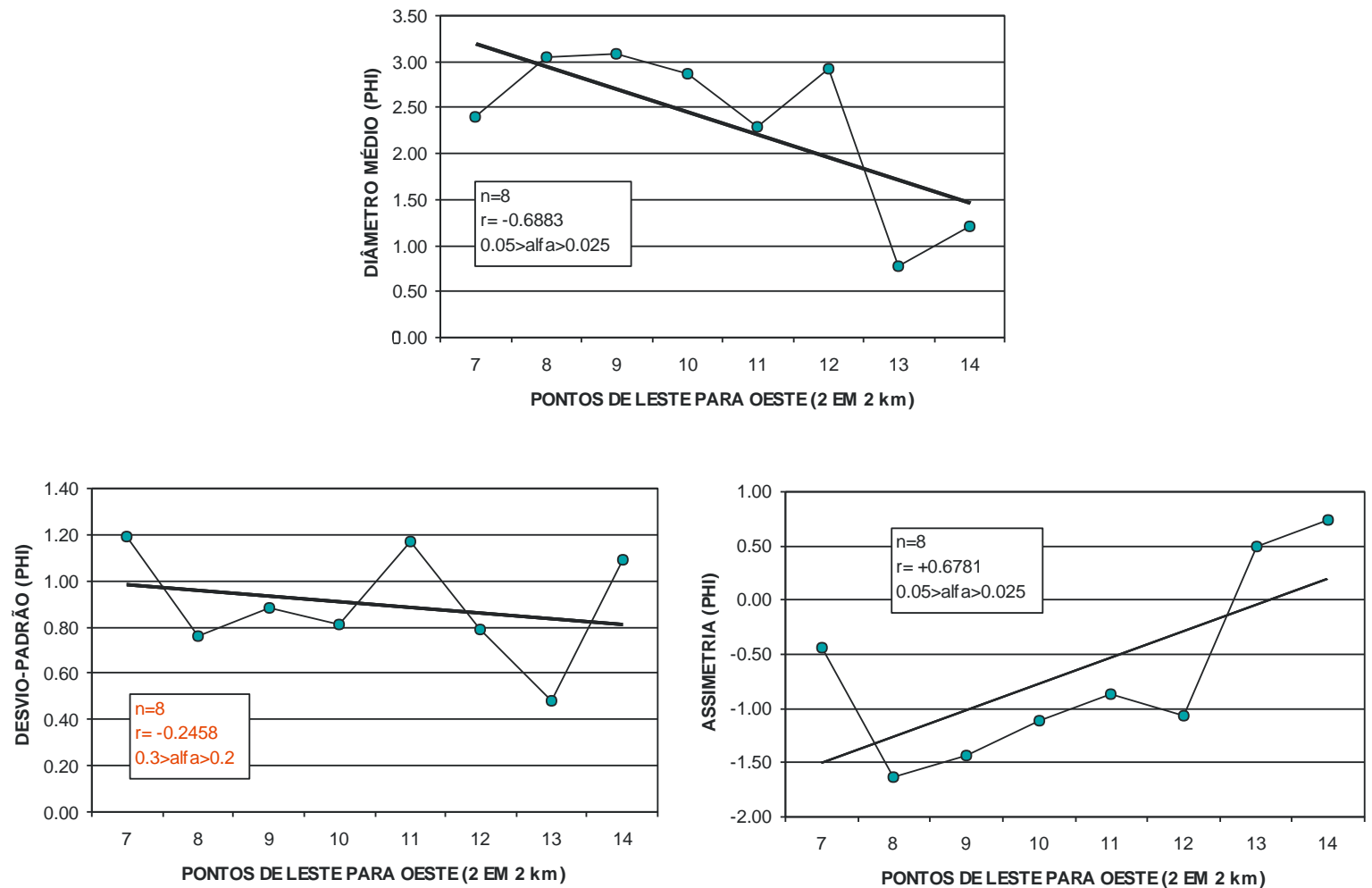

Figura 13: Comparação entre tendências de distribuição dos parâmetros estatísticos granulométricos de areias praiais entre os pontos 7 e 14 (rumo EW). Os símbolos $\mathrm{n}, \mathrm{r}$ e $\alpha$ correspondem respectivamente a número de amostras, coeficiente de correlação linear e nível de significância (por teste de regressão unicaudal t de Student).

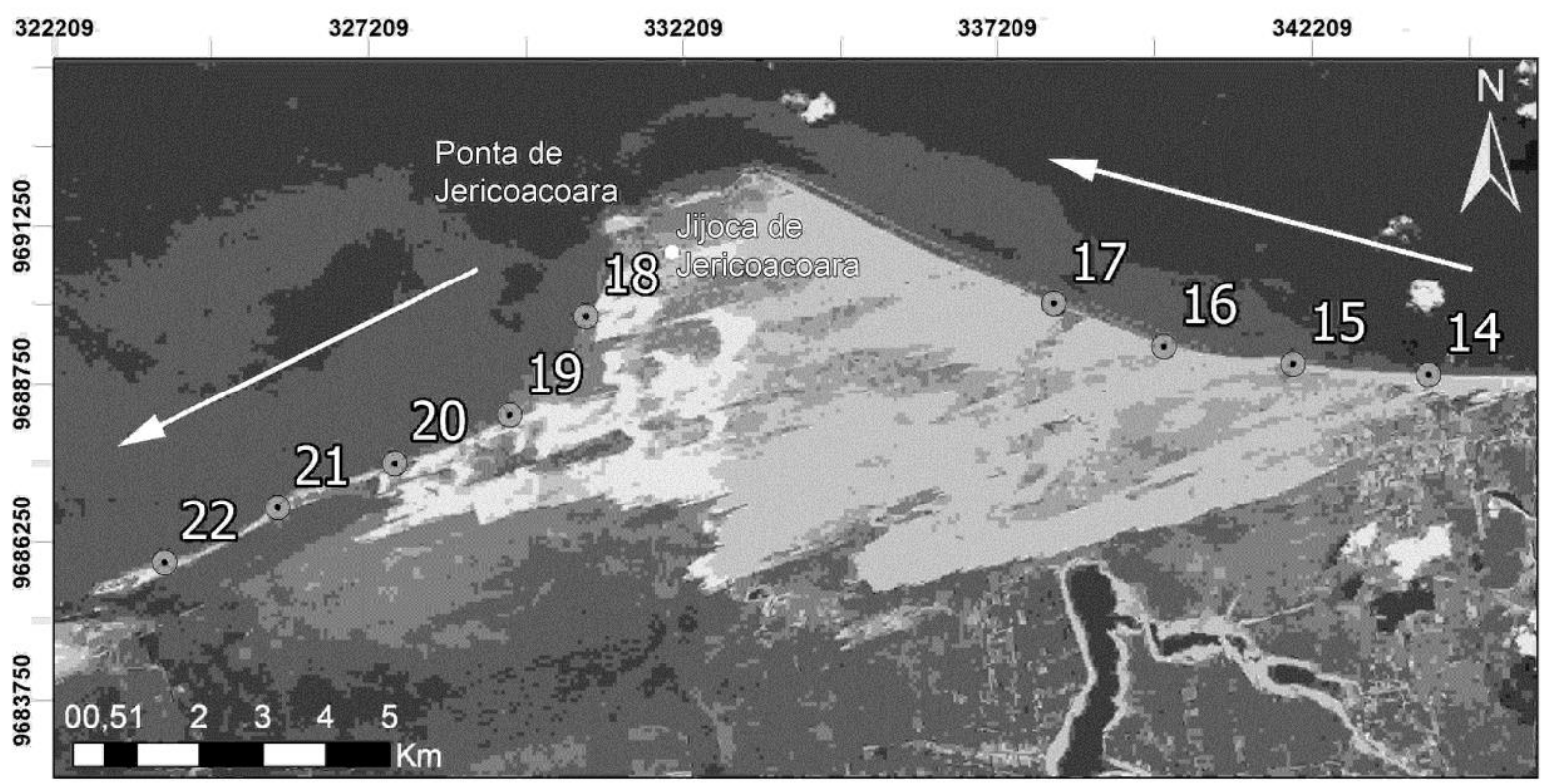

Figura 14: Ponta de Jericoacoara, com padrões de transporte do caso B concordantes com a deriva regional para oeste. Data da imagem: 16/11/2012. 

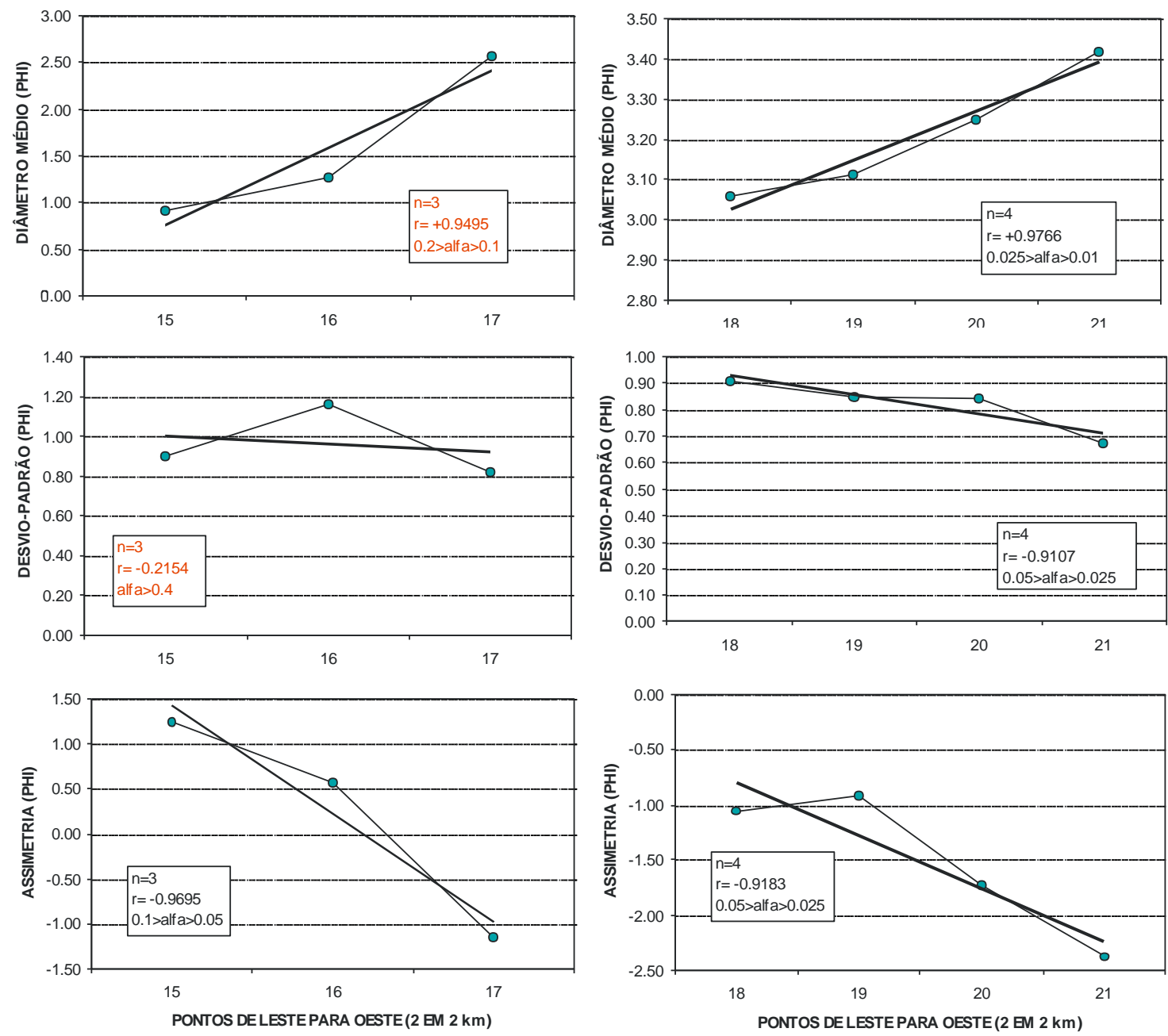

Figura 15: Comparação entre tendências de distribuição dos parâmetros estatísticos granulométricos de areias praiais entre os pontos 15 e 17 (gráficos da esquerda) e entre 18 e 21 (gráficos da direita), rumo E-W. Os símbolos n, $\mathrm{r}$ e $\alpha$ correspondem respectivamente a número de amostras, coeficiente de correlação linear e nível de significância (por teste de regressão unicaudal t de Student).

\subsubsection{Pontos 23-33: praia de Tatajuba e ilha do Amor (Camocim)}

A zona costeira a oeste do rio Guriú (Jijoca de Jericoacoara) até a desembocadura do rio Coreaú (Camocim) compreende uma extensão de $25 \mathrm{~km}$ entre a praia da Tatajuba e a chamada Ilha do Amor. Esta última, em particular, corresponde à porção mais externa de uma série de ilhas e ilhotas (com áreas de até poucos $\mathrm{km}^{2}$ ) separadas por vários canais de maré de diferentes hierarquias, onde uma extensa vegetação de mangue se desenvolve concentrada no lado leste do rio Coreaú. Atualmente, a porção denominada "ilha" encontra-se na verdade anexada à praia de Tatajuba em seu lado leste (figura 16).

$\mathrm{O}$ resultado para esse trecho litorâneo apresenta inversão local do caso B de correntes longitudinais em relação ao da deriva litorânea regional (figura 17). Este trecho litorâneo foi convenientemente subdividido em duas partes a partir do ponto 28 , devido a uma forte mudança na orientação da linha de costa entre a praia de Tatajuba (E-W) e a ilha do Amor (NE-SW).

$\mathrm{Na}$ ilha do Amor, a aparente inversão em relação à deriva regional ocorre estatisticamente pobre $(\alpha>0,1$ em todos os parâmetros), o que põe em xeque a validade do resultado geral. Isso sugere a necessidade de uma análise das areias entre os trechos mencionados para integrá-los, região onde ocorre ainda um esporão arenoso alongado no sentido W. Caso ocorra, a inversão pode ser função do bloqueio hidráulico da corrente de deriva regional exercido pela descarga fluvial do rio Coreaú, situação semelhante à vista para o lado leste do rio Acaraú. Aqui, porém, os baixios de maré são ligeiramente mais estreitos $(<1 \mathrm{~km})$. No entanto, a diferença no avanço da linha de costa entre as margens leste (Ilha do Amor) e oeste (Camocim) do rio Coreaú é maior do que no rio Acaraú: chega a 2,5 $\mathrm{km}$, situação que poderia manter o bloqueio hidráulico mesmo durante a estofa da maré. 


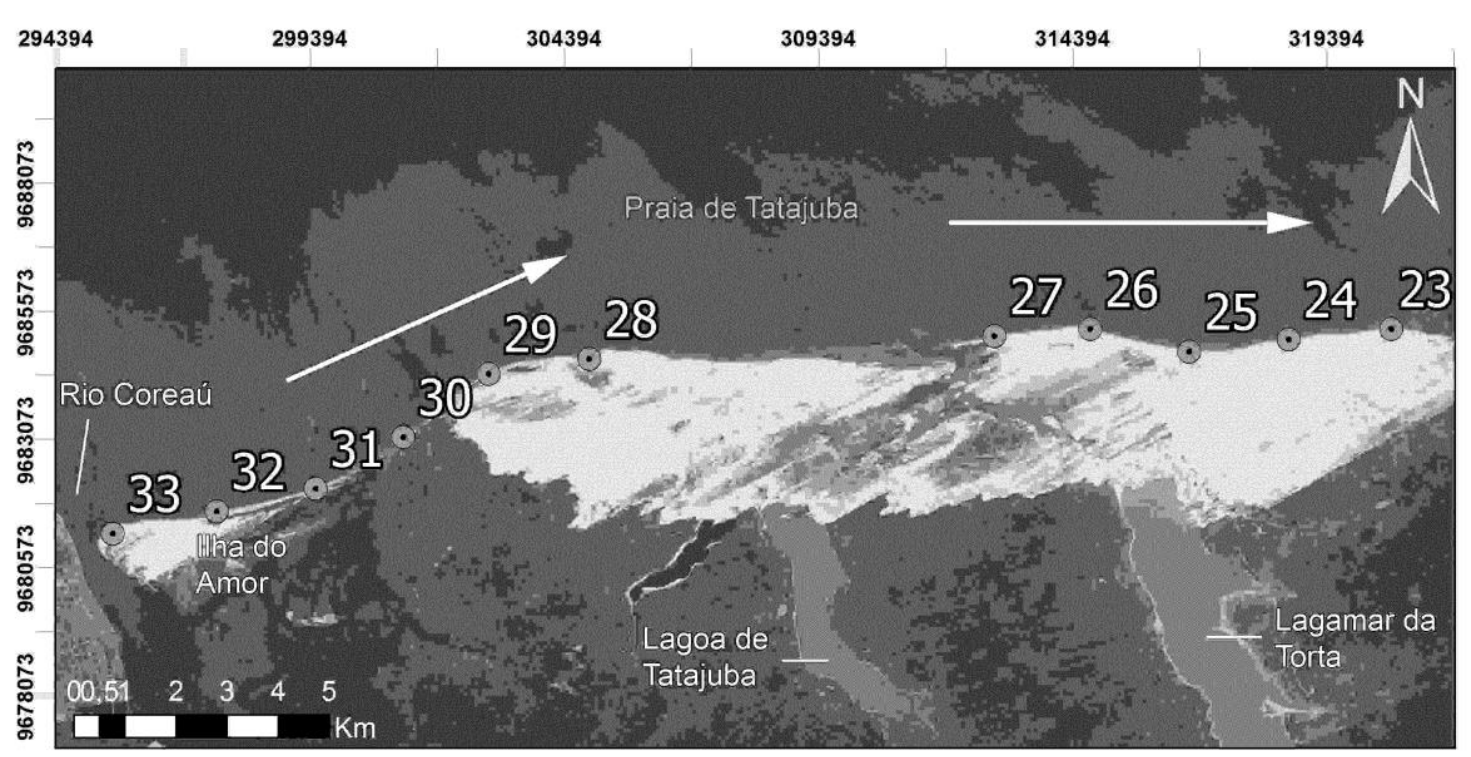

Figura 16: Praia de Tatajuba e Ilha do Amor, com padrões de transporte do caso B invertidos em relação à deriva regional para oeste. Data da imagem: $16 / 11 / 2012$.
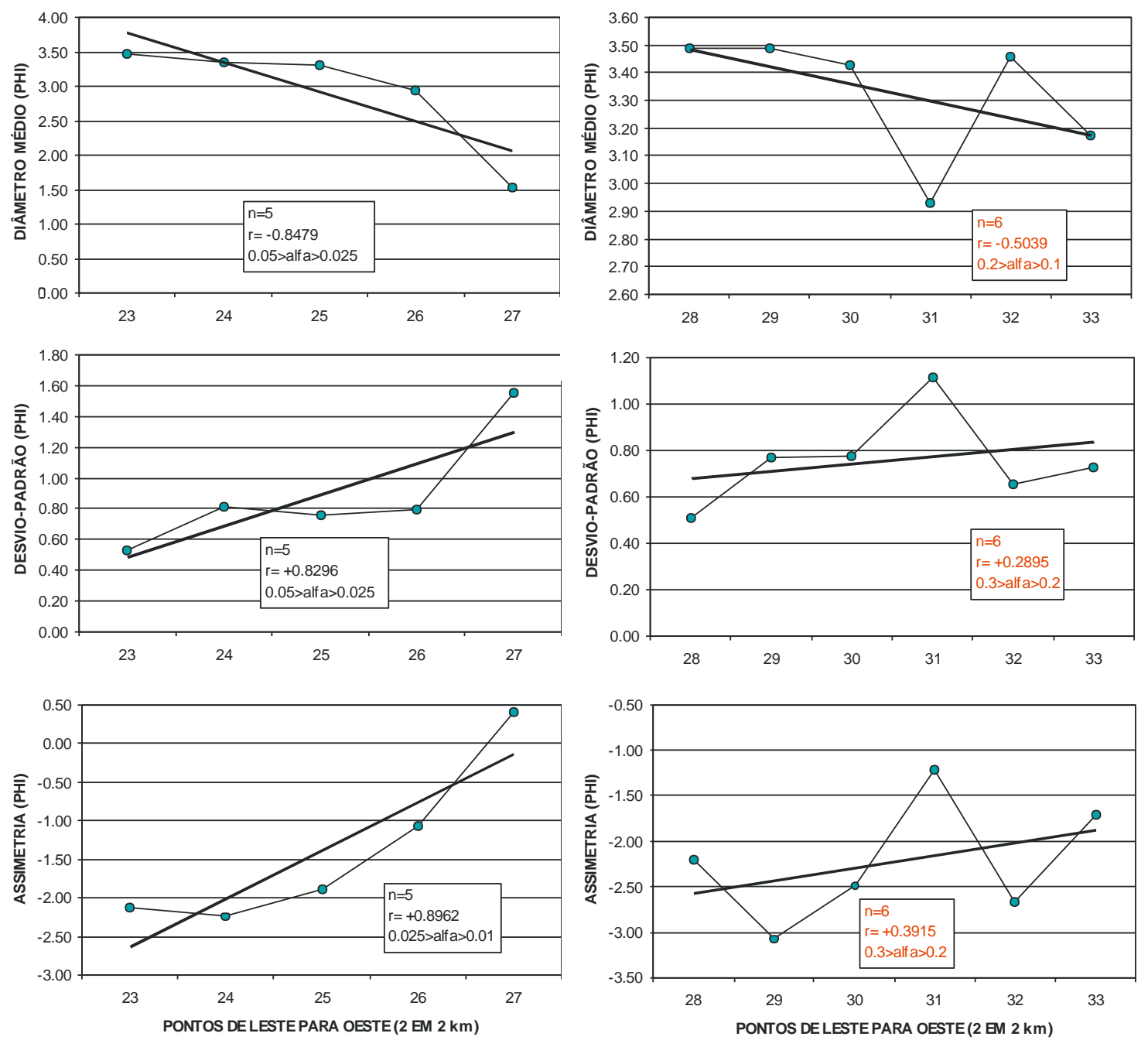

Figura 17: Comparação entre tendências de distribuição dos parâmetros estatísticos granulométricos de areias praiais entre os pontos 23 e 27 (gráficos da esquerda) e entre 28 e 33 (gráficos da direita), rumo E-W. Os símbolos $\mathrm{n}, \mathrm{r}$ e $\alpha$ correspondem respectivamente a número de amostras, coeficiente de correlação linear e nível de significância (por teste de regressão unicaudal t de Student). 


\section{Minerais Pesados}

O sistema praia - duna frontal entre Itarema e Camocim apresentou areias na fração muito fina compostas, em média, de $2,7 \%$ em massa de minerais pesados $(0,1 \%$ nas praias, $3,7 \%$ nas dunas $)$. Desses, foram separados, em média, 46,3\% de magnéticos (51,6\% nas praias, $25,5 \%$ nas dunas). $\mathrm{O}$ teor em massa de minerais pesados quantificado ao longo da praia apresentou aumento rumo W (figura 18).

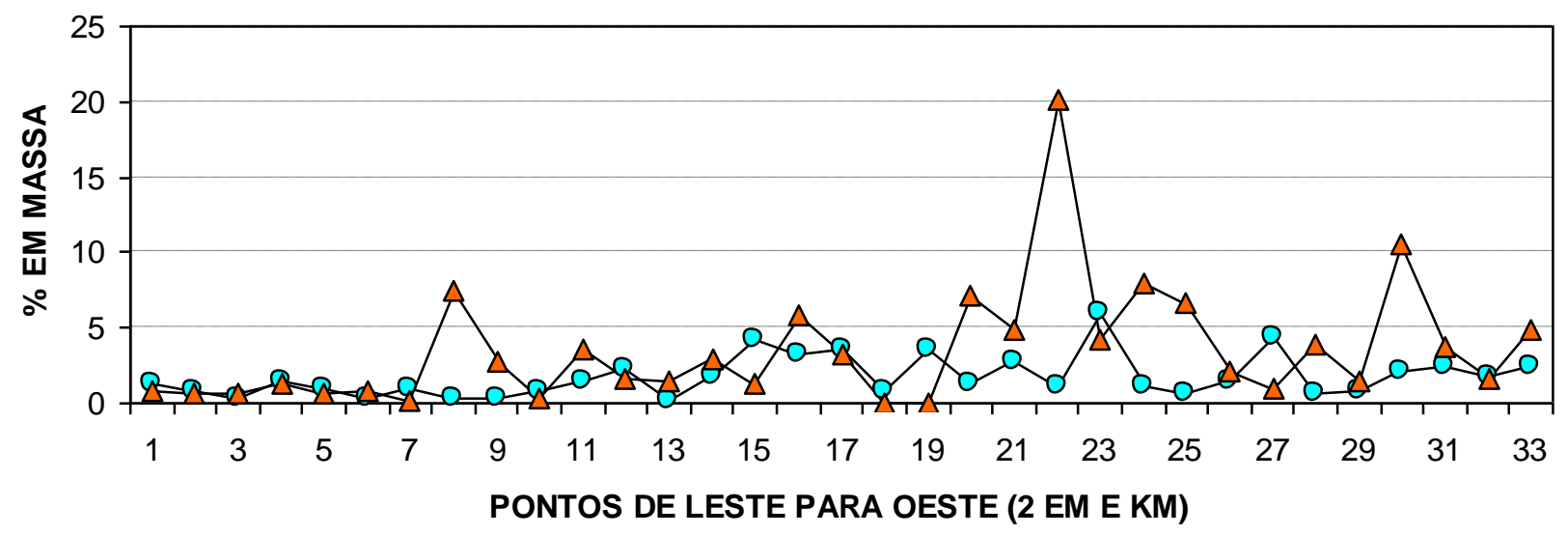

Figura 18: Porcentagem em massa de minerais pesados das frações areia fina e muito fina das praias e dunas frontais incipientes de E para W. Para fins de comparação gráfica, o teor das praias foi multiplicado por 10.

$\mathrm{O}$ aumento para oeste de minerais pesados sugere que seu controle se dá antes por fontes locais a regionais do que pelo transporte por deriva litorânea (Nascimento 2006, Nascimento et al. 2008, Guedes et al. 2011), onde neste último caso o esperado seria redução no mesmo rumo. Corrobora para isso a grande oscilação nos teores ao longo do trecho estudado. Também por isso a presença local de várias desembocaduras de drenagens estuarinas (Itarema, Imburana, Arpoeiras, Acaraú, Guriú e Coreaú), a despeito de sua vazão limitada, teria considerável influência nesse resultado.

\section{1. Áreas-fontes}

Entre os minerais pesados não-magnéticos, a proporção de opacos é de 4,2\% em média e, entre os transparentes, a quantidade de grãos alterados (alteritas) chega a $21,5 \%$. Os minerais pesados transparentes não micáceos (MPTNM) mais abundantes identificados foram (ordem decrescente de abundância): zircão $(31,4 \%)$, hornblenda verde $(20,9 \%)$, leucoxênio $(11 \%)$, cianita $(7,2 \%)$, sillimanita $(4,5 \%)$, epídoto $(4,4 \%)$, rutilo $(4,2 \%)$, turmalina parda $(3,9 \%)$, andaluzita $(2,6 \%)$, estaurolita $(1,9 \%)$, titanita $(1,4 \%)$, clinozoisita $(1,4 \%)$, clinopiroxênio incolor $(1,2 \%)$ e fibrolita (1\%). Em menor quantidade (traços: menos de $1 \%$ do total da fração MPTNM, em frequência de contagem), também foram encontrados hornblenda marrom, zoisita, granada, anatásio, hiperstênio, apatita, augita, limonita e glauconita (figura 19).
A proveniência primária geral dos minerais neste trabalho indica fontes principalmente de origem metamórfica orto e paraderivada de alto grau e origem ígnea plutônica. Minerais como zircão com cristais alongados e hornblenda apresentam origem em ambientes ígneos plutônicos ácidos e aluminosos. Cianita, andaluzita, sillimanita, e estaurolita apontam para origem em rochas de metamorfismo paraderivado de médio a alto grau. Epídoto, rutilo, turmalina parda, clinozoisita, zoisita, fibrolita e clinopiroxênio, por sua vez, enfatizam o caráter metamórfico de alto grau das fontes. A proveniência primária dos minerais deve relacionar-se com gnaisses migmatizados e xistos do Domínio Médio Coreaú, além dos metatexitos da Unidade Canindé, o granito Meruoca e os migmatitos e paragnaisses da Unidade Independência. Leucoxênio, titanita e anatásio, todos titaníferos e em associação, podem possuir como área fonte secundária a Formação Barreiras, por se tratar de unidade sedimentar antiga capaz de gerar subprodutos de alteração pedogenética e diagenética (ilmenita, titanita $\rightarrow$ leucoxênio, anatásio), como visto em praias da costa sul capixaba (Nascimento et al. 2011); a ilmenita, não quantificada neste estudo, é abundante entre os opacos da plataforma continental do oeste cearense (Almeida et al. 2011). Por fim, a presença de glauconita, mineral autígeno formado em sedimentos marinhos rasos (por halmirólise da ilita: Suguio 1980), apresenta provável fonte primária na plataforma continental adjacente à área de estudo. 

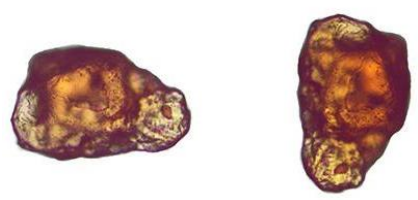

ica30p_Est

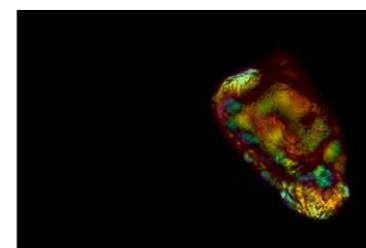

ica30p_Est
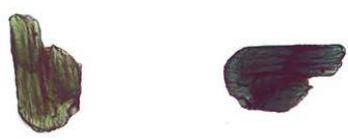

ica03p_HblV

ica03p_HbIV
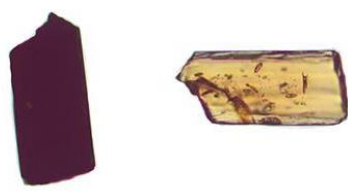

ica14d_Turm

ica14d_Turm

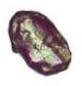

4

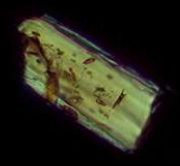

ica11p_Tit

ica11p_Tit

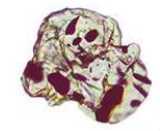

ica03p_And

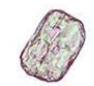

ica28p_Clz

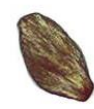

icaRA_Fib

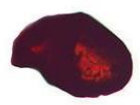

ica28d_Rut

ica18p_Zir

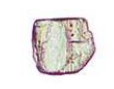

ica28d_Cian

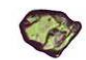

ica26d_Epi

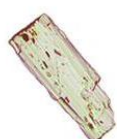

ica12p_Sil
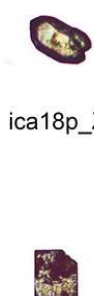

ica06p_Glau

ica07p_Anat

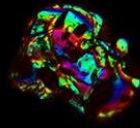

ica03p_And

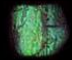

ica28d_Cian

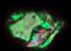

ica28p_Clz

ica26d_Epi

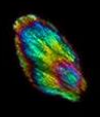

icaRA_Fib

ica12p_Sil

es:

ica28d_Rut

ica18o_Zir

\section{$0,10 \mu \mathrm{m}$}

Figura 19: Exemplares selecionados dos minerais pesados transparentes mais abundantes. Símbolos: est: estaurolita; hblv: hornblenda verde; tur: turmalina (parda); tit: titanita; and: andaluzita; cian: cianita; clz: clinozoisita; epi: epídoto; fib: fibrolita; sil: sillimanita; rut: rutilo; zir: zircão; glau: glauconita; anat: anatásio. Nicóis paralelos à esquerda (fundo branco), e cruzados à direita (fundo preto). 
Tabela 2. Porcentagem (\%) de MPTs nos rios de maior porte da região de estudo e nos sistemas deposicionais estudados. O símbolo "-" denota pequena ocorrência (traços, $<1 \%$ em média) ou ausência.

\begin{tabular}{l|c|c|c|c}
\hline \multicolumn{1}{c|}{ Minerais Pesados } & Rio Acaraú & Rio Coreaú & Média Praias & Média Dunas \\
\hline zircão & 5,4 & 23,8 & 21,5 & 42 \\
hornblenda verde & 23,6 & 2,3 & 25,3 & 16,2 \\
cianita & 12,7 & 2,3 & 5,2 & 9,3 \\
sillimanita & 7,2 & - & 6 & - \\
epídoto & 12,7 & 7,1 & 5,8 & 3 \\
rutilo & - & 4,7 & 1 & 7,5 \\
turmalina parda & - & 7,1 & 3,9 & 3,9 \\
andaluzita & 7,2 & 4,7 & 3,8 & 1,4 \\
estaurolita & - & 4,7 & 3 & - \\
titanita & 1,8 & 1,1 & 1,7 & - \\
clinozoisita & - & 2,3 & 2,2 & - \\
clinopiroxênio incolor & - & 1,1 & -3 \\
fibrolita & 18,1 & - & 1,5 & - \\
hornblenda marrom & - & 1,1 & 1,5 & - \\
zoisita & 1,8 & - & - & - \\
granada & 1,8 & 2,3 & - & - \\
anatásio & - & 2,3 & - & - \\
apatita & - & 2,3 & - & - \\
augita & 3,6 & - & - & - \\
hiperstênio & 1,8 & 1,1 & - & - \\
\hline
\end{tabular}
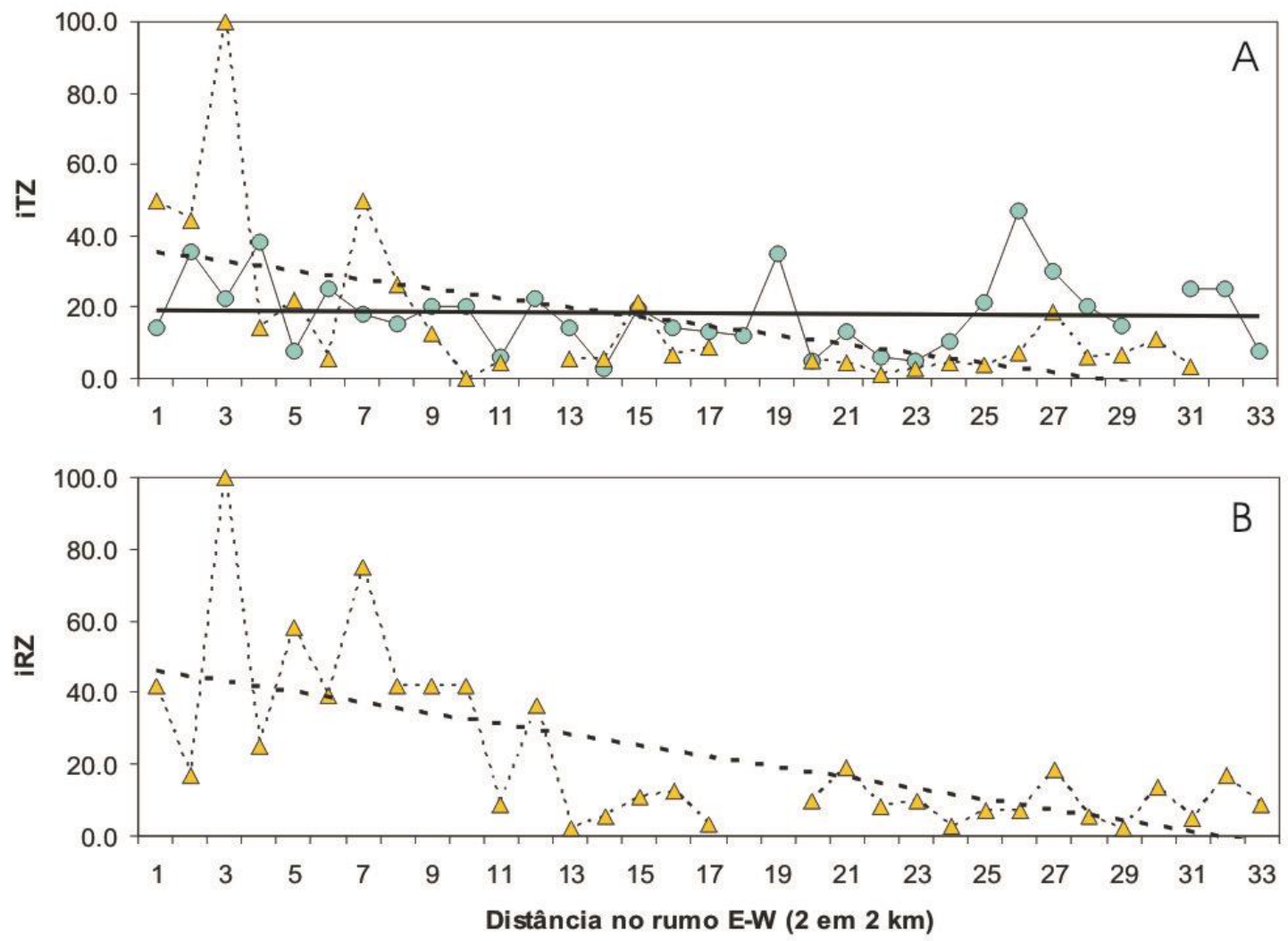

Figura 20: Variação dos índices turmalina-zircão (iTZ, em A) e rutilo-zircão (iRZ, em B) na fração areia muito fina das praias (círculos azuis) e das dunas (triângulos alaranjados) e suas respectivas linhas de tendência, de E para W, ao longo do sistema praia - duna frontal entre Itarema e Camocim. Entre os pontos e nas linhas de tendências as linhas contínuas denotam amostras de praias e, as tracejadas, amostras de dunas.

A comparação de tipos e porcentagem de minerais pesados transparentes (MPTs) entre as potenciais fontes secundárias imediatas (rios Acaraú e Coreaú) e os sistemas deposicionais estudados apresenta boa concordância, uma vez que as diferenças em teor, na maioria dos casos, não ultrapassam $10 \%$ (Tabela 2). As exceções mais destacadas são zircão, hornblenda verde e fibrolita. No primeiro caso, interpreta-se que seleção eólica voltada para intervalos de classe mais finos tenha favorecido aumento relativo de zircão, mineral tipicamente fornecido com tamanhos reduzidos $(<0,125 \mathrm{~mm})$ já a partir das fontes primárias (Pettijohn et al. 1987). No caso da hornblenda, seu fornecimento reduzido pelo Rio Coreaú seria compensado na zona costeira pelo teor mais alto do Rio Acaraú, cuja foz fica a barlamar da deriva litorânea regional. Já para a fibrolita, que é uma variedade fibrosa da sillimanita, interpreta-se uma maior fragilidade mecânica por abrasão durante o transporte por deriva litorânea. 


\section{2. Índices de transporte e de proveniência}

Para calcular o índice de transporte das areias de praia e de duna foram escolhidos turmalina e zircão (iTZ) na relação $[\mathrm{T} /(\mathrm{T}+\mathrm{Z})] \mathrm{x} 100$. Estes minerais possuem a mesma resistência ao intemperismo químico e físico (ambos ultraestáveis: Pettijohn 1975), fontes potencialmente similares e formato prismático (Mange \& Maurer 1992). Como a densidade relativa da turmalina é menor que a do zircão, pressupõe-se o transporte preferencial do primeiro mineral ao longo do sistema praial (Morton \& Hallsworth 1994). No entanto, o resultado mostra que há diminuição relativa de turmalina para oeste, quando o comportamento esperado devido ao rumo da deriva litorânea regional (para oeste) seria de aumento (figura 20). Isso pode ser devido a um maior efeito local das inversões no sentido de transporte por deriva litorânea, como apontado pela análise granulométrica, e/ou enriquecimento local renovado por desembocaduras de diferentes portes.Para calcular o índice de proveniência sedimentar, foram selecionados zircão e rutilo (iRZ) que são minerais ultraestáveis de origem potencialmente distinta (ígnea e metamórfica, respectivamente) (Guedes et al. 2011), segundo a relação $[R /(R+Z)]$ x 100 . Este índice foi calculado apenas para areias de duna, pois diversas amostras das areias de praia não apresentaram sequer um dos dois minerais do índice. Uma vez que as praias são tipicamente a fonte imediata de areias para as dunas frontais, o teor reduzido em rutilo nas praias da região do estudo não possui até agora uma explicação plausível, como no caso do zircão, que já é fornecido em tamanho reduzido desde as rochas-fontes (Pettijohn et al. 1987). Independente de qual seja a razão para isso, neste caso, o valor do índice RZ diminuiu para oeste (redução relativa de rutilo). Esta diferença pode decorrer do fato de o Rio Acaraú (a leste) captar drenagens predominantemente sobre terrenos metamórficos, embora apresente uma quantidade maior de corpos graníticos nas proximidades à montante. $\mathrm{O}$ Rio Coreaú (a oeste), comparativamente, capta mais nascentes em terrenos ígneos (suíte granítica Meruoca), fornecendo assim maiores quantidades de zircão, e menores de rutilo.

\section{Conclusões}

A diversidade morfológica do sistema praia-duna frontal entre Itarema e Camocim inclui, em escala maior, o predomínio de esporões alongados segundo a deriva litorânea regional, a leste, e de praias anexadas sem interrupções com formas eólicas mais extensas, a oeste. Em escala menor, as variedades morfológicas observadas neste estudo não apresentaram tendências claras ao longo do trecho estudado, exceto pelo aumento de declividade acompanhada pelo estreitamento das praias. Com respeito unicamente aos depósitos eólicos, a maior extensão horizontal das formas livres a oeste (no pós-praia à sotavento das DFIs) pode ser função do maior espaço de acumulação disponível ininterruptamente.
A comparação entre os três primeiros momentos de Pearson (diâmetro médio, desvio padrão e assimetria) da distribuição granulométrica das areias de praias e dunas foi verificada por correlação linear entre seus resultados para o grupo total de amostras. Bons níveis de significância foram encontrados, sendo os melhores $(\alpha<0,005)$ entre desvio-padrão e assimetria (praias), e entre desvio-padrão e assimetria com o diâmetro médio (dunas frontais). A distribuição dos momentos de Pearson das areias praiais para todo o intervalo amostrado $(100 \mathrm{~km})$ condiz com a deriva litorânea regional para oeste e ressalta o poder interpretativo dos parâmetros de McLaren \& Bowles (1985). O resultado se deu para transporte do caso B, com grãos ativamente transportados pela corrente, onde ocorre afinamento, melhora do grau de seleção e assimetria mais negativa rumo oeste. Para as dunas frontais incipientes adjacentes aos pontos amostrados nas praias, o resultado se inverte para diâmetro médio e assimetria. Este último fator ressalta a capacidade seletora do vento naquela região, apesar do curto transporte. Para desvio-padrão, o resultado nas dunas oscila em demasia seu valor ponto a ponto, e dificulta uma tendência indicativa de variação longitudinal.

Em intervalos menores (até poucas dezenas de quilômetros), ficou demonstrado que o bloqueio físico exercido pela descarga fluvial dos grandes rios na deriva regional é capaz de permitir o transporte no sentido oposto por correntes longitudinais que de outro modo seriam sobrepujadas. Os grandes rios da região, Acaraú e Coreaú, são os principais responsáveis por esse tipo de efeito. Este resultado, porém, possui ressalvas, pois carece de robustez estatística em alguns trechos e reforça assim a necessidade de uma amostragem mais detalhada das areias em termos de distribuição espacial. Por este motivo, a combinação entre vetores de deriva litorânea local não pôde indicar com segurança áreas susceptíveis a mudanças na linha de costa, seja por erosão ou deposição.

A proximidade da desembocadura de algumas drenagens menores, em particular, gerou alguns maus indicadores de transporte marinho nos locais onde houve mistura com areias fluviais/estuarinas pouco retrabalhadas no sistema praial. Em Itarema, locais com obras recentes de cata-ventos de energia eólica e viveiros de carcinicultura podem constituir fator adicional de mistura de areias imaturas trazidas de locais diversos e retrabalhadas pela deriva litorânea local.

O resultado da análise de minerais pesados aponta para fontes primárias predominantemente metamórficas de grau médio a alto (principalmente cianita, andaluzita, sillimanita e estaurolita) e ígneas plutônicas (zircão e hornblenda alongados). Rochas com potencial fornecimento primário encontram-se no Domínio Médio Coreaú, com destaque para gnaisses e migmatitos das unidades Canindé e Independência, e granito Meruoca. Quanto às fontes secundárias, minerais titaníferos de origem pedogenética e/ou diagenética podem ter sua origem na Fm. Barreiras, 
enquanto glauconita atestaria para sedimentos fornecidos a partir da plataforma continental adjacente à área de estudo. $\mathrm{O}$ índice de transporte turmalinazircão (iTZ) parece condicionado a inversões locais no transporte ou fornecimento mineral renovado. Já o índice de proveniência rutilo-zircão (iRZ) aponta para aumento relativo da proveniência plutônica nas porções mais a oeste.

\section{Agradecimentos}

Os autores agradecem ao Laboratório de Geotécnica (DG/CC/UFC) pelo apoio nos ensaios de concentração e confecção de lâminas de minerais pesados. L.N.C.T. agradece à Fundação Cearense de Apoio ao Desenvolvimento Científico e Tecnológico por sua bolsa de Iniciação Científica (PIBIC-FUNCAP).

\section{Referências}

ANA - Agência Nacional de Águas 2016. Disponível em: http://www2.ana.gov.br/Paginas/default.aspx. Acessado em 2 de dezembro de 2016

Almeida A.R., Parente C.V., Arthaud M.H. 2008. Mapa Geológico da Folha Itatira SB.24-V-B-V: nota explicativa integrada com Quixeramobim e Boa Viagem. Fortaleza, Convênio CPRM/UFC, 196p., escala 1:100.000.

Almeida N.M., Lehugeur L.G.O., Freire G.S.S., Santos D.M., Neto A.B.A. 2011. Assembleia de minerais pesados da Plataforma Continental - porção oeste do Estado do Ceará. Revista de Geologia 24(1): 21-27.

Arthaud M.H. 2007. Evolução neoproterozóica do grupo Ceará (Domínio Ceará Central, BE Brasil): da sedimentação à colisão continental brasiliana. Tese de doutorado. Pós-Graduação em Geologia, Universidade de Brasília, 170p.

Blatt H. 1967. Provenance determinations and recycling of sediments. Journal of Sedimentary Petrology, 37: 1031-1044.

Branco M.P.N.C., Lehugeur L.G.O., Campos J.E.G., Nogueira S.R.P. 2005. Morfodinâmica das praias arenosas à barlamar e à sotamar do promontório Ponta do Iguape - Estado do Ceará - Brasil. Revista de Geologia, 18(2): 215-229.

Cavalcante J.C., Vasconcelos A.M., Medeiros M.F., Paiva I.P., Gomes F.E.M., Cavalcante S.N., Cavalcante J.E., Melo A.C.R., Duarte Neto V.C. 2003. Mapa Geológico do Estado do Ceará. Fortaleza, Serviço Geológico do Brasil (CPRM), escala 1:500.000.

Cavalcante I.N., Gomes M.C.R. 2011. As águas subterrâneas do Ceará: ocorrências e potencialidades. In: Medeiros C.N., Gomes D.D.M., Albuquerque E.L.S., Cruz M.L.B. (orgs.) Os recursos hídricos do Ceará: integração, gestão e potencialidades. Editora Ipece, Fortaleza, 165-199p.

Claudino-Sales V., Peulvast J. P. 2004. Barreiras e flechas litorâneas no Estado do Ceará. RECIFE: Anais do XIX Simpósio da ABEQUA, CD-ROM.

COGERH - Companhia de Gestão de Recursos Hídricos do Estado do Ceará 2010. Plano de Gerenciamento das Águas da Bacia do Coreaú - Síntese do Relatório Final. Disponível em: http://www.ceara.gov.br/?secretaria=COGERH\&endereco=http:/ /portal.cogerh.com.br/. Acessado em 2 de dezembro de 2016.

Complexo Portuário do Pecém (CPP). 2001. Medições de correntes, salinidade e temperatura na área marítima do Pecém. Associação Téc. Cient. Engo. Paulo de Frontin, Universidade Federal do Ceará (Fortaleza). Relatório Interno, 157p.

Dean R.G. 1973. Heuristic models of sand transport in the surf zone. In: Proceedings of the Conference on Engineering Dynamics in the Surf Zone, Sydney, 208-214p.

Diretoria de Hidrografia e Navegação (DHN). 2003. Disponível em: http://www.mar.mil.br/dhn/chm/box-previsao-mare/tabuas/. Acessado em 11 de maio de 2017

Folk R.L. 1968. Petrology of sedimentary rocks. The University of Texas, Austin, 170 p.
Fujimori S., Ferreira Y.A. 1979. Introdução ao uso do microscópio petrográfico. Editora da UFBA, Salvador, 240p.

Galehouse J.S. 1971. Point counting. In: Carver R.E. (org.) Procedures in Sedimentary Petrology. Wiley-Interscience, New York, 385-407p.

Giannini P.C.F., Machado J.A., Santos E.R. 2003. Propriedades granulométricas no sistema praia-duna ao longo da costa noroeste portuguesa, de Porto a Nazaré. In: IX Congresso da ABEQUA, Recife, 1 CD-ROM.

Gonçalves R.S.B. 2006. Estudo geofísico do arcabouço estrutural da Bacia Jaibaras - CE. Trabalho de Conclusão de Curso. Bacharelado em Geologia, Departamento de Geologia, Universidade Federal do Ceará, 54p.

Guedes C.C.F., Giannini P.C.F., Nascimento Jr. D.R., Sawakuchi A.O., Tanaka A.P.B., Rossi M.G. 2011. Controls on heavy minerals and grain size in a Holocene regressive barrier (Ilha Comprida, Southeastern Brazil). Journal of South American Earth Sciences, 31: 110-123.

Hesp P.A. 2000. Coastal sand dunes. Form and function. CDNV Technical Bulletin No. 4. Massey University, 28 p.

Hesp P.A., Maia L.P., Claudino-Sales V. 2009. The Holocene barriers of Maranhão, Piauí and Ceará States, Northeastern Brazil. In: Dillenburg S.R., Hesp P.A. (eds.) Geology and geomorphology of Holocene coastal barriers of Brazil. SpringerVerlag, Berlim, 390p.

Hoefel F.G. 1998. Morfodinâmica de Praias Arenosas Oceânicas Uma Revisão Bibliográfica. Editora da Univale, Itajaí, 92p.

Instituto Nacional de Meteorologia (INMET) 2017. Disponível em: www.inmet.gov.br/. Acessado em 11 de maio de 2017.

Kerr P.F. 1959. Optical mineralogy. McGraw Hill, New York, 372p.

Lima L.C., Morais J.O., Souza M.J.N. 2000. Compartimentação territorial e gestão regional do Ceará. Editora Funece, Fortaleza, $268 \mathrm{p}$.

Magini C., Gomes D.F., Veríssimo C.U.V., Freire G.S.S., Paiva Neto A.O. 2007. Avaliação Ambiental da Praia do Futuro, Município de Fortaleza, Ceará. Revista de Geologia, 1: 20-32.

Maia L.P. 1998. Procesos costeros y balance sedimentario a lo largo de Fortaleza (NE-Brasil): Implicaciones pra una gestión adecuada del litoral. Barcelona: Tesis Doctoral, Universidad de Barcelona, 269p

Maia P., Nascimento P., Junior A.P. 2003. Parabéns Guarapari, 112 anos de emancipação política. Jornal A Gazeta (Caderno Especial), 3-15p

Mange M.A., Maurer H.F.W. 1992. Heavy minerals in colour. Chapman \& Hall, London, 147 p.

Mcgregor G.R., Nieuwolt S. 1998. Tropical Climatology - An Introduction to the climates of the low latitudes, Wiley, New York, 339p.

Mclaren P., Bowles D. 1985. The effects of sediment transport on grain-size distributions. Journal of Sedimentary Petrology, 55(4): 457-470.

Morais J.O., Souza J.V. 1971. Transporte e sedimentação de dunas no município de Fortaleza (Ceará - Brasil). Estudos Sedimentológicos, 1(1): 73-81.

Morton A.C., Hallsworth C.R. 1994. Identifying provenance-specific features of detrital heavy mineral assemblages in sandstones. Sedimentary Geology, 90(1): 241-256.

Muehe D. 1996. Geomorfologia Costeira. In: Cunha S.B., Guerra A.J.T. (eds.) Geomorfologia - Exercícios, Técnicas e Aplicações. Editora Bertrand Brasil, Rio de Janeiro, 191-233p.

Nascimento Jr. D.R. 2004. Dinâmica e sedimentação da Praia da Areia Preta (Guarapari - ES). Trabalho de Conclusão de Curso. Bacharelado em Geologia, Departamento de Geociências, Universidade Federal Rural do Rio de Janeiro. Trabalho de Conclusão de Curso (inéd.), 113p.

Nascimento Jr. D.R. 2006. Morfologia e sedimentologia ao longo do sistema praia - duna frontal de Ilha Comprida. Dissertação de Mestrado. Pós-Graduação em Geociências, Instituto de Geociências, Universidade de São Paulo, 136p.

Nascimento Jr. D.R., Tanaka A.P.B., Giannini P.C.F., Guedes C.C.F. 2005. Morfologia e granulometria ao longo do sistema praia duna frontal da Ilha Comprida, SP. In: X Congresso da ABEQUA, Guarapari, 1 CD-ROM

Nascimento Jr. D.R., Giannini P.C.F., Tanaka A.P.B., Guedes, C.C.F. 2008. Mudanças morfológicas da extremidade NE da Ilha 
Comprida (SP) nos últimos dois séculos. Geologia USP Série Científica, 8(1): 25-39.

Nascimento Jr. D.R., Aguiar V.A.P., Giannini P.C.F. 2011. Minerais pesados das areias praiais de Guarapari (ES): distribuição, proveniência e fatores de risco à saúde. In: XIII Congresso da ABEQUA, Búzios, 1 CD-ROM.

Nascimento F.S., Freire G.S.S., Miola B. 2009. Caracterização geoquímica dos granulados marinhos da plataforma continental do Nordeste do Brasil. Revista de Geologia, 22(1): 15-26.

Nimer E. 1979. Climatologia do Brasil. IBGE - Série Recursos Naturais e Meio Ambiente, Rio de Janeiro, 421p.

Parente C.V., Botelho N.F., Santos R.V., Garcia M.G.M., Oliveira C. G., Veríssimo, C.U.V. 2011. Contexto geológico, tipológico e geoquímico isotópico das brechas hidrotermalizadas de ferro e cobre tipo IOCG, associadas a bacia Eo-Paleozóica Jaibaras, da Província Borborema, Brasil. In: Frantz J.C., Marques J., Jost H. (orgs.) Contribuições à metalogenia do Brasil. UFRGS, Porto Alegre, 175-198p.

Pettijohn F.J. 1975. Sedimentary Rocks. Harper \& Row, New York, 628 p.

Pettijohn F.J., Potter P.E., Siever R. 1987. Sand and Sandstone. Springer-Verlag Inc., New York, 553p.

Sawakuchi A.O., Kalchgruber R., Giannini P.C.F., Nascimento Jr. D.R., Guedes C.C.F., Umisedo N.K. 2008. The development of blowouts and foredunes in the Ilha Comprida barrier (Southeastern Brazil): the influence of Late Holocene climate changes on coastal sedimentation. Quaternary Science Reviews, 27: 2076-2090.

Sial A.N., Figueiredo M.C.H., Long L.E. 1981. Rare-earth element geochemistry of the Meruoca and Mucambo Plutons, Ceará, Northeast Brazil. Chemical Geology, 31: 271-283.

Sucupira P.A.P., Pinheiro L.S., Rosa M.F. 2006. Caracterização Morfométrica do Médio e Baixo Curso do Rio Acaraú, Ceará, Brasil. In: VI Simpósio Nacional de Geomorfologia, Goiânia, 1$10 \mathrm{p}$.

Suguio K. 1980. Rochas Sedimentares - Propriedades, Gênese e Importância Econômica. 4a. reimp. São Paulo: Editora Edgard Blücher Ltda., 500 p.

Trögger W.E. 1979. Optical determination of rock-forming minerals, part 1: determination tables. Schweizerbart'sche Verlagsbuchhandlung, Stuttgart, 188p.

Vaz P.T, Rezende N.G.A.M, Wanderley J.R., Travassos A.S. 2007. Bacia do Parnaíba. Boletim de Geociências da Petrobras, 15(2): 253-263.

Vidal R.M.B., Becker H., Freire G.S.S. 2008. Geoquímica de sedimentos da plataforma continental do Estado do Ceará Brasil. Revista de Geologia, 21(2): 223-232.

Wentworth C.A. 1922. A scale of grade and class terms for clastic sediments. Journal of Geology, 30: 377-392.

Wright L.D., Short A.D. 1984. Morphodynamic variability of surf zones and beaches: a synthesis. Marine Geology, 56: 93-118.

Recebido 06 de março de 2017 Aceito 14 de agosto de 2017 